NBER WORKING PAPER SERIES

\title{
RE-ASSESSING THE U.S. QUALITY ADJUSTMENT \\ TO COMPUTER PRICES: \\ THE ROLE OF DURABILITY AND CHANGING SOFTWARE
}

\author{
Robert C. Feenstra \\ Christopher R. Knittel \\ Working Paper 10857 \\ http://www.nber.org/papers/w10857
NATIONAL BUREAU OF ECONOMIC RESEARCH
1050 Massachusetts Avenue
Cambridge, MA 02138
October 2004

Prepared for the CRIW conference "Index Theory \& Measurement of Price and Productivity," June 28-29, 2004, Vancouver, B.C. We thank Bert Balk and the participants of the CRIW conference for helpful comments. We thank Roger Butters and Konstantinos Metaxoglou for research assistance. We benefitted greatly from discussions with Lanier Benkard at an early stage of the research, who also provided data, for which we are grateful. The views expressed herein are those of the author(s) and not necessarily those of the National Bureau of Economic Research.

(C2004 by Robert C. Feenstra and Christopher R. Knittel. All rights reserved. Short sections of text, not to exceed two paragraphs, may be quoted without explicit permission provided that full credit, including () notice, is given to the source. 
Re-Assessing the U.S. Quality Adjustment to Computer Prices: The Role of Durability and Changing Software

Robert C. Feenstra and Christopher R. Knittel

NBER Working Paper No. 10857

October 2004

JEL No. D2, E3, L6

\begin{abstract}
$\underline{\text { ABSTRACT }}$
In the second-half of the 1990s, the positive impact of information technology on productivity growth for the United States became apparent. The measurement of this productivity improvement depends on hedonic procedures adopted by the Bureau of Labor Statistics (BLS) and Bureau of Economic Analysis (BEA). In this paper we suggest a new reason why conventional hedonic methods may overstate the price decline of personal computers. We model computers as a durable good and suppose that software changes over time, which influences the efficiency of a computer. Anticipating future increases in software, purchasers may "overbuy" characteristics, in the sense that the purchased bundle of characteristics is not fully utilized in the first months or year that a computer is owned. In this case, we argue that hedonic procedures do not provide valid bounds on the true price of computer services at the time the machine is purchased with the concurrent level of software. To assess these theoretical results we estimate the model and find that before 2000 the hedonic price index constructed with BLS methods overstates the fall in computer prices. After 2000, however, the BLS hedonic index falls more slowly, reflecting the reduced marginal cost of acquiring (and therefore marginal benefit to users) of characteristics such as RAM, hard disk space or speed.
\end{abstract}

Robert C. Feenstra

Department of Economics

University of California

Davis, CA 95616

and NBER

rcfeenstra@ucdavis.edu
Christopher R. Knittel

Department of Economics

University of California

Davis, CA 95616

and NBER

crknittel@ucdavis.edu 


\section{Introduction}

In the second-half of the 1990s, the positive impact of information technology (IT) on productivity growth for the United States became apparent (Jorgenson and Stiroh, 2000, Oliner and Sichel, 2000). The measurement of this productivity improvement depends on hedonic procedures adopted by the Bureau of Labor Statistics (BLS) and Bureau of Economic Analysis (BEA). These procedures include the hedonic adjustment of prices for mainframes and peripherals since 1985 (Cole et al, 1986, Cartwright and Smith, 1988), for personal computers (PC's) since 1991 (Holdway, 2001), and for semiconductors since 1996 (Grimm, 1998). ${ }^{1}$ The rapid price declines of these products means that their production and use accounts for a sizable portion of recent U.S. productivity gains.

It is sometimes suggested that the price declines in IT products may be overstated due to the use of hedonic techniques, though this belief has not been confirmed. Triplett (1999), for example, critiques a number of suggested reasons why the hedonic techniques might overstate the price decline of IT products, but he generally finds that these reasons are not persuasive. Empirically, Landefeld and Grimm (2000) show that the hedonic adjustments used in official statistics closely match those recommended by academic studies, such as Berndt and Rappaport (2001), so there is no presumption of a downward bias in the official calculations. But concern about this potential bias will no doubt continue. ${ }^{2}$

In this paper we suggest a new reason why conventional hedonic methods may overstate the price decline of personal computers, which are treated here as a durable good. We suppose

\footnotetext{
1 See Moulton (2001) who details the use of hedonic methods in U.S. statistical agencies.

2 For semiconductors, Aizcorbe (2004) argues that falling price-cost margins by selling firms may accentuate the price decline. Gordon (2000) presents a different reason why the TFP contribution of IT capital may be overstated. He argues that the increase in TFP during the second-half of the 1990s is a cyclical rather than trend increase, and by focusing only on the trend, the contribution of IT capital to productivity is smaller. Conversely, Benkard and Bajari (2003) argue that standard hedonic index can be upward biased due to unobserved characteristics.
} 
that software changes over time, which influences the efficiency of a computer. Anticipating the future increases in software, purchasers may "overbuy" characteristics, in the sense that the purchased bundle of characteristics is not fully utilized in the first months or year that a computer is owned. Forward looking buyers will equate the marginal benefits of characteristics over the lifetime of a machine to the marginal cost at the time of purchase. This means that the marginal costs are equated to marginal benefits evaluated at future levels of software. In this case, we argue that hedonic procedures do not provide valid bounds on the true price of computer services at the time the machine is purchased with the concurrent level of software.

There are two ways that this concern might influence calculations of total factor productivity (TFP). Following Oliner and Sichel (2000), let us make the distinction between the use of IT capital and the production of IT capital. The use of IT capital will influence TFP calculations through the measurement of the IT capital stock. This will require depreciation rates for computer equipment, and if changes in software influences the efficiency of a machine then depreciation rates should reflect this. We do not attempt to solve that problem here, though our framework could likely be adapted to address it. ${ }^{3}$ Rather, we focus on the production of IT capital, and in particular, on the hedonic price index constructed for personal computers, as in Holdway (2001). This hedonic index can be used to construct dual TFP for personal computers, i.e. as the difference between weighted growth in factor prices within that sector and the growth in the hedonic output price. If the hedonic output price is intended to reflect the efficiency of new machines to users at the current level of software, then we argue that conventional hedonic methods may well overstate this price decline.

\footnotetext{
3 Overviews of the measurement of capital and depreciation rates are provided by Diewert (1980), Harper, Berndt and Wood (1989), and Hulten (1990), though only Diewert (1980, pp. 503-506) includes a discussion of hedonics. Specific discussion of depreciation for computers is in Oliner (1993) and Harper (2001).
} 
We begin the analysis in section 2 by describing a case where the conventional hedonic adjustment provides a valid measure for the true services price of computers, similar to Rosen (1974) or Pakes (2003), though we allow for purchases of multiple units. In that section, it is assumed that the computers being purchased are nondurable. In section 3 we analyze the case where computers are durable and software is changing over time. We find that conventional hedonic methods do not provide valid bounds to the true price of computer services (evaluated with current levels of software). The extent to which the true services price deviates from the conventional hedonic index will depend on the interaction between software and characteristics in the services that buyers' obtain from the machine. If software and characteristics are complements, in the sense that anticipated increases in software will lead the buyer to purchase more characteristics today, then it is more likely that the conventional hedonic methods will overstate the true price decline.

To assess these theoretical results, in sections 4 and 5 we estimate the model in a twostep procedure. First, monthly hedonic regressions are run over a sample of desktop PC's, from August 1997 to September 2001. Second, we utilize a dataset of all purchases of PC's at the University of California, Davis over similar dates. In the second step, the estimated hedonic coefficients are regressed on the characteristics actually purchased each month and a weighted average of software quality over the lifetime of the machine. The coefficients obtained in this second step reveal the users" "production functions" by which characteristics and software are transformed into computer services. Therefore, we can use these coefficients to obtain the true services price for users, and compare this with the bounds obtained from conventional hedonic methods. 
It turns out that our results differ in the first and second-halves of our sample. Before 2000, we generally find that the hedonic price index constructed with BLS methods overstates the fall in computer prices, as compared to the true price index constructed using the estimated production functions for users. This accords with our theoretical results. Furthermore, we find that the true services price falls faster when it is evaluated with future rather than current levels of software. This corresponds to our intuition that characteristics may be overbought, so their value with current software is less than with future software, and the true price index with current software is above the price index with future software.

After 2000, however, the BLS hedonic index falls more slowly, reflecting the reduced marginal cost of acquiring (and therefore marginal benefit to users) of characteristics such as RAM, hard disk space or speed. Depending on the starting month, by the end of 2001 it turns out that the BLS index matches quite closely the true production function index constructed with current software. In this sense, the overstatement of the price decline by BLS methods has been ameliorated in recent years. The production function index constructed with future software falls faster than either of the other two indexes, however, which is explained by the forthcoming release of Windows XP and 2003, with its large hardware requirements. Additional conclusions are provided in section 6 .

\section{Buyer's Problem With Nondurable Capital}

In his classic treatment, Rosen (1974) considers the problem of buyers and sellers who purchase and produce differentiated goods. Under his assumptions (perfect competition and many varieties) this results in an equilibrium price schedule $p_{t}=h_{t}\left(x_{t}\right)$, where $x_{t} \in R^{M}$ is the vector of characteristics and $\mathrm{p}_{\mathrm{t}}$ is the price in period $\mathrm{t}$. We will take this price schedule as given and re-examine the buyer's problem, introducing one important difference from Rosen: we shall 
allow the buyer to purchase multiple units of the differentiated good, i.e. multiple computers. The reason for allowing this will become clear shortly. Since this assumption is more realistic for firms than for consumers, we will use that language to describe our model, but much the same results would hold for a consumer purchasing multiple units.

In addition to computers, the firm uses other inputs denoted by the vector $\mathrm{y}_{\mathrm{t}}$. The services obtained in year $t=1, \ldots, T$ from a computer of characteristics with $x_{t}$ is $f\left(x_{t}, s_{t}\right)$, where the vector $\mathrm{s}_{\mathrm{t}}$ denotes the state of software. We will sometimes refer to $\mathrm{f}\left(\mathrm{x}_{\mathrm{t}}, \mathrm{s}_{\mathrm{t}}\right)$ as the "production function" for the firm, and it shows how computer characteristics and software combine to create computing services. Treating the computer as a non-durable good, the firm purchases $n_{t}$ identical units in year $\mathrm{t}$, and new machines the next year. ${ }^{4}$ The computers, purchased along with other inputs $\mathrm{y}_{\mathrm{t}}$, yields per-period revenue $\mathrm{G}\left[\mathrm{y}_{\mathrm{t}}, \mathrm{n}_{\mathrm{t}} \mathrm{f}\left(\mathrm{x}_{\mathrm{t}}, \mathrm{s}_{\mathrm{t}}\right)\right]$ for the firm. Then the maximization problem is to choose $\mathrm{n}_{\mathrm{t}}, \mathrm{x}_{\mathrm{t}}$ and $\mathrm{y}_{\mathrm{t}}$ to:

$$
\max _{\mathrm{n}_{\mathrm{t}}, \mathrm{x}_{\mathrm{t}}, \mathrm{y}_{\mathrm{t}}} \mathrm{G}\left[\mathrm{y}_{\mathrm{t}}, \mathrm{n}_{\mathrm{t}} \mathrm{f}\left(\mathrm{x}_{\mathrm{t}}, \mathrm{s}_{\mathrm{t}}\right)\right]-\mathrm{n}_{\mathrm{t}} \mathrm{h}_{\mathrm{t}}\left(\mathrm{x}_{\mathrm{t}}\right)-\mathrm{q}_{\mathrm{t}} \mathrm{y}_{\mathrm{t}}
$$

where $\mathrm{p}_{\mathrm{t}}=\mathrm{h}_{\mathrm{t}}\left(\mathrm{x}_{\mathrm{t}}\right)$ is the price of a computer and $\mathrm{q}_{\mathrm{t}}$ is the price of the other inputs $\mathrm{y}_{\mathrm{t}}$.

We will let $\mathrm{K}_{\mathrm{t}} \equiv \mathrm{n}_{\mathrm{t}} \mathrm{f}\left(\mathrm{x}_{\mathrm{t}}, \mathrm{s}_{\mathrm{t}}\right)$ denote the capital stock of computers, measured in efficiency units. To compare our results with Rosen and other authors, suppose first that the number of computers purchased $n_{t}$ cannot be varied (for example, $n_{t}=1$ ). Then the first order conditions for problem (1) are:

$$
\begin{aligned}
& \mathrm{G}_{\mathrm{y}}\left[\mathrm{y}_{\mathrm{t}}, \mathrm{n}_{\mathrm{t}} \mathrm{f}\left(\mathrm{x}_{\mathrm{t}}, \mathrm{s}_{\mathrm{t}}\right)\right]=\mathrm{q}_{\mathrm{t}}, \\
& \mathrm{G}_{\mathrm{K}}\left[\mathrm{y}_{\mathrm{t}}, \mathrm{n}_{\mathrm{t}} \mathrm{f}\left(\mathrm{x}_{\mathrm{t}}, \mathrm{s}_{\mathrm{t}}\right)\right] \mathrm{n}_{\mathrm{t}} \mathrm{f}_{\mathrm{x}}\left(\mathrm{x}_{\mathrm{t}}, \mathrm{s}_{\mathrm{t}}\right)=\mathrm{n}_{\mathrm{t}} \mathrm{h}_{\mathrm{t}}{ }^{\prime}\left(\mathrm{x}_{\mathrm{t}}\right),
\end{aligned}
$$

\footnotetext{
4 We could generalize the problem to allow the firm to choose several type of computers, each in multiple units, by giving it several service functions $\mathrm{f}\left(\mathrm{x}_{\mathrm{t}}, \mathrm{s}_{\mathrm{t}}\right)$, e.g. for desktops, laptops, etc.
} 
where $h_{t}{ }^{\prime}\left(x_{t}\right)$ denotes the vector of derivatives $\left(\partial h_{t} / \partial x_{1 t}, \ldots, \partial h_{t} / \partial x_{M t}\right)$ for the $M$ characteristics.

Canceling $\mathrm{n}_{\mathrm{t}}$ from the left and right-hand side of (3), the first-order condition is interpreted as the marginal benefit of each characteristic $\left(G_{K} f_{x}\right)$ equaling its marginal cost $\left(h_{t}{ }^{\prime}\right)$. A difficulty that arises is that the marginal benefit depends on the quantity of other inputs purchased via $\mathrm{G}_{\mathrm{K}}\left[\mathrm{y}_{\mathrm{t}}, \mathrm{n}_{\mathrm{t}} \mathrm{f}\left(\mathrm{x}_{\mathrm{t}}, \mathrm{s}_{\mathrm{t}}\right)\right]$, or implicitly, on their prices $\mathrm{q}_{\mathrm{t}}$. This complicates the empirical application of hedonic methods, and several approaches have been taken to simplify the problem.

First, we could suppose that the revenue function is additively separable, so that $\mathrm{G}\left[\mathrm{y}_{\mathrm{t}}, \mathrm{n}_{\mathrm{t}} \mathrm{f}\left(\mathrm{x}_{\mathrm{t}}, \mathrm{s}_{\mathrm{t}}\right)\right]=\mathrm{g}\left(\mathrm{y}_{\mathrm{t}}\right)+\mathrm{n}_{\mathrm{t}} \mathrm{f}\left(\mathrm{x}_{\mathrm{t}}, \mathrm{s}_{\mathrm{t}}\right)$. In that case, the maximization of firm profits in (1) implies the sub-problem of choosing choose characteristics $\mathrm{x}_{\mathrm{t}}$ to:

$$
\max _{\mathrm{x}_{\mathrm{t}}} \mathrm{f}\left(\mathrm{x}_{\mathrm{t}}, \mathrm{s}_{\mathrm{t}}\right)-\mathrm{h}_{\mathrm{t}}\left(\mathrm{x}_{\mathrm{t}}\right)
$$

for which the first-order condition is simply $f_{x}\left(x_{t}, s_{t}\right)=h_{t}{ }^{\prime}\left(x_{t}\right)$. This formulation of the problem is implicitly used by Pakes (2003), for example. Second, we could reformulate the buyer's problem in terms of its dual, and carry along the prices $\mathrm{q}_{\mathrm{t}}$ of the other goods in the first-order conditions. Diewert (2003) takes this approach and shows how an aggregate of the prices $\mathrm{q}_{\mathrm{t}}$ affects the hedonic price surface.

Third, the approach we shall take is to allow the firm to optimally choose the number of computers $\mathrm{n}_{\mathrm{t}}$. This implies the additional first-order condition:

$$
G_{K}\left[y_{t}, n_{t} f\left(x_{t}, s_{t}\right)\right] f\left(x_{t}, s_{t}\right)=h_{t}\left(x_{t}\right)
$$

Combining (3) and (5) we readily obtain:

$$
\frac{h_{t}{ }^{\prime}\left(x_{t}\right)}{h_{t}\left(x_{t}\right)}=\frac{f_{x}\left(x_{t}, s_{t}\right)}{f\left(x_{t}, s_{t}\right)}
$$


This shows the equality of the marginal price of characteristics with their marginal value to the user when the number of units are also chosen. It is analogous to the first-order condition derived by Rosen (1974), and has the benefit that the price or quantity of other goods purchased do not appear.

The simplicity of the first-order condition (6) will be useful empirically, but also allows a reformulation of the theoretical problem. Again letting $\mathrm{K}_{\mathrm{t}} \equiv \mathrm{n}_{\mathrm{t}} \mathrm{f}\left(\mathrm{x}_{\mathrm{t}}, \mathrm{s}_{\mathrm{t}}\right)$ denote the capital stock of computers, so that $\mathrm{n}_{\mathrm{t}}=\mathrm{K}_{\mathrm{t}} / \mathrm{f}\left(\mathrm{x}_{\mathrm{t}}, \mathrm{s}_{\mathrm{t}}\right)$, problem (1) can be re-written as:

$$
\max _{K_{t}, x_{t}, y_{t}} G\left(y_{t}, K_{t}\right)-K_{t}\left(\frac{h_{t}\left(x_{t}\right)}{f\left(x_{t}, s_{t}\right)}\right)-q_{t} y_{t} .
$$

For the choice of characteristics $x_{t}$, it is evident that to maximize (1'), the buyer must solve the sub-problem:

$$
\min _{x_{t}} \frac{h_{t}\left(x_{t}\right)}{f\left(x_{t}, s_{t}\right)}
$$

Notice the difference between this sub-problem and that in (4): both are correct, but are obtained under slightly different assumptions. The formulation in (1') and (7) makes it clear that the price of computer services is $\mathrm{p}_{\mathrm{t}} / \mathrm{f}\left(\mathrm{x}_{\mathrm{t}}, \mathrm{s}_{\mathrm{t}}\right)=\mathrm{h}_{\mathrm{t}}\left(\mathrm{x}_{\mathrm{t}}\right) / \mathrm{f}\left(\mathrm{x}_{\mathrm{t}}, \mathrm{s}_{\mathrm{t}}\right)$, that is, the ratio of the nominal price to benefits rather than their difference in (4). We will presume that the goal of a price index is to measure the change over time in the "true" services price $\mathrm{p}_{\mathrm{t}} / \mathrm{f}\left(\mathrm{x}_{\mathrm{t}}, \mathrm{s}_{\mathrm{t}}\right)$.

The first-order conditions for (7) are just (6), and the simple statement of the problem also allows the second-order conditions to be easily examined. Minimizing (7) is equivalent to minimizing its natural log, and a sufficient second-order condition for a local minimum are: 


$$
\left[\frac{\partial^{2} \ln h_{t}\left(x_{t}\right)}{\partial x_{t}^{2}}-\frac{\partial^{2} \ln f\left(x_{t}, s_{t}\right)}{\partial x_{t}^{2}}\right] \text { is positive definite around } x_{t}
$$

Consider the case where the price function for computers, $\mathrm{h}_{\mathrm{t}}\left(\mathrm{x}_{\mathrm{t}}\right)$, takes on the semi-log form, $\ln p_{t}=\ln h_{t}\left(x_{t}\right)=\alpha_{t}+\beta_{t}{ }^{\prime} x_{t}$. Then (8) is satisfied if and only if $\ln f\left(x_{t}, s_{t}\right)$ is concave in a neighborhood around $x_{t}$. We state a slightly stronger version of this second-order condition as one possible assumption:

\section{Assumption 1}

(a) $h_{t}\left(x_{t}\right)$ is semi-log in $x_{t}, \ln p_{t}=\ln h_{t}\left(x_{t}\right)=\alpha_{t}+\beta_{t}{ }^{\prime} x_{t}, t=1, \ldots, T$;

(b) $\ln f(x, s)$ is concave in $x$ in an open convex region that includes $\left(x_{t}, s_{t}\right), t=1, \ldots, T$, where the characteristics and software are non-decreasing over time, $\left(\mathrm{x}_{\mathrm{t}-1}, \mathrm{~s}_{\mathrm{t}-1}\right) \leq\left(\mathrm{x}_{\mathrm{t}}, \mathrm{s}_{\mathrm{t}}\right)$.

The assumption that $\left(\mathrm{x}_{\mathrm{t}-1}, \mathrm{~S}_{\mathrm{t}-1}\right) \leq\left(\mathrm{x}_{\mathrm{t}}, \mathrm{s}_{\mathrm{t}}\right)$ in part $(\mathrm{b})$ is made for notational convenience, and could be weakened. Note that by letting $x_{t}=\ln z_{t}$ for underlying characteristics $z_{t}$, then Assumption 1 can also be used for the log-log hedonic price function.

Clearly, parts (a) and (b) of Assumption 1 go together: with other assumptions on the functional form of the hedonic regression $h_{t}\left(x_{t}\right)$, there would be alternative properties for $f\left(x_{t}, s_{t}\right)$ implied by the second-order conditions. For example, suppose that we treated $h_{t}\left(x_{t}\right)$ as linear in $\mathrm{x}_{\mathrm{t}}$ rather than semi-log. By twice differentiating (1) with respect to $\mathrm{x}_{\mathrm{t}}$, it is easy to show that the second-order condition is satisfied if $\mathrm{G}\left(\mathrm{y}_{\mathrm{t}}, \mathrm{K}_{\mathrm{t}}\right)$ is concave in $\mathrm{K}_{\mathrm{t}}$ and $\mathrm{f}\left(\mathrm{x}_{\mathrm{t}}, \mathrm{s}_{\mathrm{t}}\right)$ is concave in $\mathrm{x}_{\mathrm{t}}$. We state this as an alternative assumption: 


\section{$\underline{\text { Assumption } 2}$}

(a) $\mathrm{h}_{\mathrm{t}}\left(\mathrm{x}_{\mathrm{t}}\right)$ is linear in $\mathrm{x}_{\mathrm{t}}, \mathrm{p}_{\mathrm{t}}=\mathrm{h}_{\mathrm{t}}\left(\mathrm{x}_{\mathrm{t}}\right)=\alpha_{\mathrm{t}}+\beta_{\mathrm{t}}{ }^{\prime} \mathrm{x}_{\mathrm{t}}, \mathrm{t}=1, \ldots, \mathrm{T}$;

(b) $f(x, s)$ is concave in $x$ in an open convex region that includes $\left(x_{t}, s_{t}\right), t=1, \ldots, T$, where the characteristics and software are non-decreasing over time, $\left(\mathrm{x}_{\mathrm{t}-1}, \mathrm{~s}_{\mathrm{t}-1}\right) \leq\left(\mathrm{x}_{\mathrm{t}}, \mathrm{s}_{\mathrm{t}}\right)$.

The BLS actually uses a linear hedonic regression (Holdway, 2001), but we will derive results that hold under either Assumptions 1 or 2.

The BLS makes a hedonic adjustment to computer prices to deflate the output of the computer sector within the producer price index. This price index then becomes an input price to sectors using computers, where we expect the hedonically-adjusted price index to reflect the cost of services obtained. To describe this in terms of problem (1'), the "true" price of computer services is $\mathrm{p}_{\mathrm{t}} / \mathrm{f}\left(\mathrm{x}_{\mathrm{t}}, \mathrm{s}_{\mathrm{t}}\right)$, or the nominal price deflated by the services obtained from a machine. Let $\mathrm{P}^{0}\left(\mathrm{p}_{\mathrm{t}-1}, \mathrm{p}_{\mathrm{t}}, \mathrm{x}_{\mathrm{t}-1}, \mathrm{x}_{\mathrm{t}}\right)$ and $\mathrm{P}^{1}\left(\mathrm{p}_{\mathrm{t}-1}, \mathrm{p}_{\mathrm{t}}, \mathrm{x}_{\mathrm{t}-1}, \mathrm{x}_{\mathrm{t}}\right)$ denote two alternative measures of a constant-quality price ratio for a computer model between years $\mathrm{t}-1$ and $\mathrm{t}$, i.e. with constant characteristics. We wish to use these measures to obtain bounds on the true services price $\mathrm{p}_{t} / f\left(\mathrm{x}_{t}, \mathrm{~s}_{\mathrm{t}}\right)$, such that:

$$
\mathrm{P}^{0}\left(\mathrm{p}_{\mathrm{t}-1}, \mathrm{p}_{\mathrm{t}}, \mathrm{x}_{\mathrm{t}-1}, \mathrm{x}_{\mathrm{t}}\right) \geq \frac{\mathrm{p}_{\mathrm{t}} / \mathrm{f}\left(\mathrm{x}_{\mathrm{t}}, \mathrm{s}_{\mathrm{t}}\right)}{\mathrm{p}_{\mathrm{t}-1} / \mathrm{f}\left(\mathrm{x}_{\mathrm{t}-1}, \mathrm{~s}_{\mathrm{t}}\right)}
$$

and,

$$
\mathrm{P}^{1}\left(\mathrm{p}_{\mathrm{t}-1}, \mathrm{p}_{\mathrm{t}}, \mathrm{x}_{\mathrm{t}-1}, \mathrm{x}_{\mathrm{t}}\right) \leq \frac{\mathrm{p}_{\mathrm{t}} / \mathrm{f}\left(\mathrm{x}_{\mathrm{t}}, \mathrm{s}_{\mathrm{t}-1}\right)}{\mathrm{p}_{\mathrm{t}-1} / \mathrm{f}\left(\mathrm{x}_{\mathrm{t}-1}, \mathrm{~s}_{\mathrm{t}-1}\right)}
$$

The right side of (9) is the ratio of the price of computers services, but measured at a constant level of software $\left(\mathrm{s}_{\mathrm{t}}\right.$ or $\left.\mathrm{s}_{\mathrm{t}-1}\right)$. If the inequalities in (9) hold, then we have obtained bounds on the change in the true services price, using the constant-quality price ratios $\mathrm{P}^{0}$ and $\mathrm{P}^{1}$. Provided that these bounds are similar, then we conclude that the use of either one provides a good measure of the change in the services price for that computer. 
In practice, BLS constructs the producer price index for personal computers as follows (Holdway, 2001). Let $\mathrm{p}_{\mathrm{t}}=\mathrm{h}_{\mathrm{t}}\left(\mathrm{x}_{\mathrm{t}}\right)=\alpha_{\mathrm{t}}+\beta_{\mathrm{t}}{ }^{\prime} \mathrm{x}_{\mathrm{t}}$ denote the linear hedonic regression, $\mathrm{t}=1, \ldots, \mathrm{T}$. Then $\mathrm{h}_{\mathrm{t}}\left(\mathrm{x}_{\mathrm{t}-1}\right)=\mathrm{p}_{\mathrm{t}}-\beta_{\mathrm{t}}{ }^{\prime}\left(\mathrm{x}_{\mathrm{t}}-\mathrm{x}_{\mathrm{t}-1}\right)$ measures the price in year $\mathrm{t}$ minus an adjustment for the changed characteristics between the two years. Triplett (1986) refers to this as making an "explicit hedonic adjustment" to the period t price. The ratio of prices in year $\mathrm{t}$ and $\mathrm{t}-1 \mathrm{with}$ constant characteristics is:

$$
\mathrm{P}^{0}\left(\mathrm{p}_{\mathrm{t}-1}, \mathrm{p}_{\mathrm{t}}, \mathrm{x}_{\mathrm{t}-1}, \mathrm{x}_{\mathrm{t}}\right) \equiv \frac{\mathrm{h}_{\mathrm{t}}\left(\mathrm{x}_{\mathrm{t}-1}\right)}{\mathrm{p}_{\mathrm{t}-1}}=\frac{\left[\mathrm{p}_{\mathrm{t}}-\beta_{\mathrm{t}}{ }^{\prime}\left(\mathrm{x}_{\mathrm{t}}-\mathrm{x}_{\mathrm{t}-1}\right)\right]}{\mathrm{p}_{\mathrm{t}-1}}
$$

While (10) is the method used by BLS, it is straightforward to consider alternative ways to make the hedonic adjustment. In particular, rather than adjusting the period t price in (10a), we could instead adjust the period t-1 price, obtaining:

$$
\mathrm{P}^{1}\left(\mathrm{p}_{\mathrm{t}-1}, \mathrm{p}_{\mathrm{t}}, \mathrm{x}_{\mathrm{t}-1}, \mathrm{x}_{\mathrm{t}}\right) \equiv \frac{\mathrm{p}_{\mathrm{t}}}{\mathrm{h}_{\mathrm{t}-1}\left(\mathrm{x}_{\mathrm{t}}\right)}=\frac{\mathrm{p}_{\mathrm{t}}}{\left[\mathrm{p}_{\mathrm{t}-1}+\beta_{\mathrm{t}-1}{ }^{\prime}\left(\mathrm{x}_{\mathrm{t}}-\mathrm{x}_{\mathrm{t}-1}\right)\right]}
$$

We would expect the indexes $\mathrm{P}^{0}$ and $\mathrm{P}^{1}$ to be quite close in practice, provided that the price surface $h_{t}\left(x_{t}\right)$ is not changing too rapidly over time.

The particular form for the hedonic correction used in (10) depends on the functional form of $h_{t}\left(x_{t}\right)$. If instead we suppose that $\ln p_{t}=\ln h_{t}\left(x_{t}\right)=\alpha_{t}+\beta_{t}{ }^{\prime} x_{t}$ is semi-log, $t=1, \ldots, T$, then the constant-quality price ratios are:

$$
\mathrm{P}^{0}\left(\mathrm{p}_{\mathrm{t}-1}, \mathrm{p}_{\mathrm{t}}, \mathrm{x}_{\mathrm{t}-1}, \mathrm{x}_{\mathrm{t}}\right) \equiv \frac{\mathrm{h}_{\mathrm{t}}\left(\mathrm{x}_{\mathrm{t}-1}\right)}{\mathrm{p}_{\mathrm{t}-1}}=\frac{\mathrm{p}_{\mathrm{t}} \exp \left[-\beta_{\mathrm{t}}{ }^{\prime}\left(\mathrm{x}_{\mathrm{t}}-\mathrm{x}_{\mathrm{t}-1}\right)\right]}{\mathrm{p}_{\mathrm{t}-1}},
$$

and,

$$
\mathrm{P}^{1}\left(\mathrm{p}_{\mathrm{t}-1}, \mathrm{p}_{\mathrm{t}}, \mathrm{x}_{\mathrm{t}-1}, \mathrm{x}_{\mathrm{t}}\right) \equiv \frac{\mathrm{p}_{\mathrm{t}}}{\mathrm{h}_{\mathrm{t}-1}\left(\mathrm{x}_{\mathrm{t}}\right)}=\frac{\mathrm{p}_{\mathrm{t}}}{\mathrm{p}_{\mathrm{t}-1} \exp \left[\beta_{\mathrm{t}-1}{ }^{\prime}\left(\mathrm{x}_{\mathrm{t}}-\mathrm{x}_{\mathrm{t}-1}\right)\right]}
$$


Following Berndt and Rappaport (2001, p. 270), we define the hedonic Laspeyres and Paasche prices indexes, respectively, as (11a) and (11b) evaluated using the mean value of characteristics over the models available each period. The mean value of characteristics are also used to evaluate the expected prices, $\bar{p}_{t} \equiv h_{t}\left(\bar{x}_{t}\right), t=1, \ldots, T$. Notice that the hedonic Laspeyres index is then $\mathrm{P}^{0}=\mathrm{h}_{\mathrm{t}}\left(\overline{\mathrm{x}}_{\mathrm{t}-1}\right) / \mathrm{h}_{\mathrm{t}-1}\left(\overline{\mathrm{x}}_{\mathrm{t}-1}\right)$, which uses last-period characteristics, while the hedonic Paasche index is $\mathrm{P}^{1}=\mathrm{h}_{\mathrm{t}}\left(\overline{\mathrm{x}}_{\mathrm{t}}\right) / \mathrm{h}_{\mathrm{t}-1}\left(\overline{\mathrm{x}}_{\mathrm{t}}\right)$, which uses present-period characteristics. ${ }^{5}$

We will use (11) as the constant-quality price ratio corresponding to Assumption 1, and those in (10) for Assumption 2. The question is whether either of these provide valid bounds to the true price of computer services. The following result shows that this is indeed the case.

\section{Proposition 1}

Suppose that characteristics are chosen optimally as in (6). Then under Assumption 1 (or 2), the constant-quality price ratios defined in (10) (or 11, respectively) provide bounds to the change in the true price of computers services, so that (9) is satisfied.

The proof of Proposition 1 is in the Appendix, and follows from exploiting the concavity of $\mathrm{f}\left(\mathrm{x}_{\mathrm{t}}, \mathrm{s}_{\mathrm{t}}\right)$ or $\ln \mathrm{f}\left(\mathrm{x}_{\mathrm{t}}, \mathrm{s}_{\mathrm{t}}\right)$. Proposition 1 gives us some confidence in the hedonic adjustment made by BLS, but it obtained by ignoring issues of dynamics. The durability of computers, along with changing software, is introduced in the next section.

\footnotetext{
5 Of course, the usual Laspeyres and Paasche price indexes use last-period and present-period quantity weights, respectively. We will not have the quantities available in our dataset, so our definition of there terms in the hedonic context refers to the use of last-period and present-period characteristics. Feenstra (1995) argues that the Laspeyres and Paasche hedonic indexes provides bounds on the change in consumer welfare, analogous to Proposition 1.
} 


\section{Dynamic Problem With Changing Software}

We now suppose that a computer purchased lasts for a number of periods. The services received in period $t$ for a computer purchased in $t-\tau$ with characteristics $x_{t-\tau}$, is $f\left(x_{t-\tau}, s_{t}\right)$. We adopt the convention that if $\mathrm{f}\left(\mathrm{x}_{\mathrm{t}-\tau}, \mathrm{s}_{\mathrm{t}}\right)$ ever become negative (i.e. the computer is dysfunctional), then we redefine the value of this function at zero. The firm will continue to use this computer so long as $\mathrm{f}\left(\mathrm{x}_{\mathrm{t}-\tau}, \mathrm{s}_{\mathrm{t}}\right)>0$. Let $\overline{\mathrm{T}}$ be the longest period that any computer is held. Then the buyer solves the dynamic problem:

$$
\max _{y_{t}, n_{t}, x_{t}} \sum_{t=\bar{T}}^{\infty} \beta^{t-\bar{T}} G\left[y_{t}, \sum_{\tau=0}^{\bar{T}} n_{t-\tau} f\left(x_{t-\tau}, s_{t}\right)\right]-n_{t} h_{t}\left(x_{t}\right)-q_{t} y_{t}
$$

where $\mathrm{p}_{\mathrm{t}}=\mathrm{h}_{\mathrm{t}}\left(\mathrm{x}_{\mathrm{t}}\right)$ is again the price of a computer, $\mathrm{K}_{\mathrm{t}} \equiv \sum_{\tau=0}^{\overline{\mathrm{T}}} \mathrm{n}_{\mathrm{t}-\tau} \mathrm{f}\left(\mathrm{x}_{\mathrm{t}-\tau}, \mathrm{s}_{\mathrm{t}}\right)$ is the capital stock

measured in efficiency units, and the values of $\mathrm{n}_{\mathrm{t}}$ and $\mathrm{x}_{\mathrm{t}}$ for $\mathrm{t}<\overline{\mathrm{T}}$ are taken as given. Note that for simplicity we have treated the future state of software $s_{t}$ as known with perfect foresight.

The first-order conditions for (12) are:

$$
\begin{aligned}
& \mathrm{G}_{\mathrm{y}}\left(\mathrm{y}_{\mathrm{t}}, \mathrm{K}_{\mathrm{t}}\right)=\mathrm{q}_{\mathrm{t}}, \\
& \sum_{\tau=0}^{\overline{\mathrm{T}}} \beta^{\tau} \mathrm{G}_{\mathrm{K}}\left(\mathrm{y}_{\mathrm{t}+\tau}, \mathrm{K}_{\mathrm{t}+\tau}\right) \mathrm{f}\left(\mathrm{x}_{\mathrm{t}}, \mathrm{s}_{\mathrm{t}+\tau}\right)=\mathrm{h}_{\mathrm{t}}\left(\mathrm{x}_{\mathrm{t}}\right), \\
& \sum_{\tau=0}^{\overline{\mathrm{T}}} \beta^{\tau} \mathrm{G}_{\mathrm{K}}\left(\mathrm{y}_{\mathrm{t}+\tau}, \mathrm{K}_{\mathrm{t}+\tau}\right) \mathrm{n}_{\mathrm{t}} \mathrm{f}_{\mathrm{x}}\left(\mathrm{x}_{\mathrm{t}}, \mathrm{s}_{\mathrm{t}+\tau}\right)=\mathrm{n}_{\mathrm{t}} \mathrm{h}_{\mathrm{t}}{ }^{\prime}\left(\mathrm{x}_{\mathrm{t}}\right),
\end{aligned}
$$

Dividing (13c) by (13b), we obtain:

$$
\frac{\sum_{\tau=0}^{\bar{T}} \beta^{\tau} G_{K}\left(y_{t+\tau}, K_{t+\tau}\right) f_{x}\left(x_{t}, s_{t+\tau}\right)}{\sum_{\tau=0}^{\bar{T}} \beta^{\tau} G_{K}\left(y_{t+\tau}, K_{t+\tau}\right) f\left(x_{t}, s_{t+\tau}\right)}=\frac{h_{t}{ }^{\prime}\left(x_{t}\right)}{h_{t}\left(x_{t}\right)}
$$


as the first-order condition that defines the choice of characteristics $\mathrm{x}_{\mathrm{t}}$ for the computer(s) purchased in period $\mathrm{t}$.

This first-order condition is forward looking, in that the firm will be evaluating the marginal productivity of characteristics over the lifetime of the machine. To make this explicit, note that (14) can be rewritten as:

$$
\sum_{\tau=0}^{\bar{T}} \theta_{t, \tau} \frac{f_{x}\left(x_{t}, s_{t+\tau}\right)}{f\left(x_{t}, s_{t+\tau}\right)}=\frac{h_{t}{ }^{\prime}\left(x_{t}\right)}{h_{t}\left(x_{t}\right)}
$$

with the weights, $\theta_{t, \tau} \equiv \frac{\beta^{\tau} \mathrm{G}_{\mathrm{K}}\left(\mathrm{y}_{\mathrm{t}+\tau}, \mathrm{K}_{\mathrm{t}+\tau}\right) \mathrm{f}\left(\mathrm{x}_{\mathrm{t}}, \mathrm{s}_{\mathrm{t}+\tau}\right)}{\sum_{\tau=0}^{\bar{T}} \beta^{\tau} \mathrm{G}_{\mathrm{K}}\left(\mathrm{y}_{\mathrm{t}+\tau}, \mathrm{K}_{\mathrm{t}+\tau}\right) \mathrm{f}\left(\mathrm{x}_{\mathrm{t}}, \mathrm{s}_{\mathrm{t}+\tau}\right)}$, where $\sum_{\tau=0}^{\overline{\mathrm{T}}} \theta_{\tau, \mathrm{t}}=1$.

To simplify this first-order condition, it is convenient to adopt a specific functional form for the production function $\mathrm{f}\left(\mathrm{x}_{\mathrm{t}}, \mathrm{s}_{\mathrm{t}}\right)$. In particular, we shall adopt the translog form:

$$
\ln \mathrm{f}^{\ell}\left(\mathrm{x}_{\mathrm{t}}, \mathrm{s}_{\mathrm{t}}\right)=\mathrm{a}_{\ell}{ }^{\prime} \mathrm{x}_{\mathrm{t}}+\frac{1}{2} \mathrm{x}_{\mathrm{t}}{ }^{\prime} \mathrm{Ax} \mathrm{x}_{\mathrm{t}}+\mathrm{b}^{\prime} \mathrm{s}_{\mathrm{t}}+\frac{1}{2} \mathrm{~s}_{\mathrm{t}}{ }^{\prime} \mathrm{Bs}_{\mathrm{t}}+\mathrm{x}_{\mathrm{t}}{ }^{\prime} \Gamma \mathrm{s}_{\mathrm{t}}
$$

where $\ell=1, \ldots, \mathrm{L}$ denotes different buyers. The parameters $(\mathrm{A}, \mathrm{b}, \mathrm{B}, \Gamma)$ are constant across buyers, while we allow the marginal benefits to vary across users by the coefficients $\mathrm{a}_{\ell}$. To satisfy Assumption 1(b) the matrix A must be negative semi-definite, and we shall consider some restrictions on the matrix $\Gamma$ below.

Notice that the marginal value of characteristics, $\mathrm{f}_{\mathrm{x}}^{\ell} / \mathrm{f}^{\ell}$, is linear in the software $\mathrm{s}_{\mathrm{t}}$. It follows that by substituting (16) into (15), we can re-write the first-order condition as:

$$
\begin{aligned}
& \frac{\mathrm{f}_{\mathrm{x}}^{\ell}\left(\mathrm{x}_{\mathrm{t}}, \widetilde{\mathrm{s}}_{\mathrm{t}}\right)}{\mathrm{f}^{\ell}\left(\mathrm{x}_{\mathrm{t}}, \widetilde{\mathrm{s}}_{\mathrm{t}}\right)}=\frac{\mathrm{h}_{\mathrm{t}}{ }^{\prime}\left(\mathrm{x}_{\mathrm{t}}\right)}{\mathrm{h}_{\mathrm{t}}\left(\mathrm{x}_{\mathrm{t}}\right)}, \\
& \tilde{\mathrm{s}}_{\mathrm{t}} \equiv \sum_{\tau=0}^{\overline{\mathrm{T}}} \theta_{\mathrm{t}, \tau} \mathrm{s}_{\mathrm{t}+\tau} .
\end{aligned}
$$

where, 
That is, the marginal value of characteristics, evaluated with the average future state of software $\widetilde{s}_{t}$, equals the marginal cost of characteristics today. This first-order condition (17) takes the place of (9), as obtained with a nondurable computer, and shows that the characteristics $\mathrm{x}_{\mathrm{t}}$ chosen at time $\mathrm{t}$ are optimal for the future state of software $\widetilde{\mathrm{s}}_{\mathrm{t}}$.

Turning to the hedonic adjustment of computer prices, we continue to assume that the goal of the constant-quality price ratios $\mathrm{P}^{0}\left(\mathrm{p}_{\mathrm{t}-1}, \mathrm{p}_{\mathrm{t}}, \mathrm{x}_{\mathrm{t}-1}, \mathrm{x}_{\mathrm{t}}\right)$ and $\mathrm{P}^{1}\left(\mathrm{p}_{\mathrm{t}-1}, \mathrm{p}_{\mathrm{t}}, \mathrm{x}_{\mathrm{t}-1}, \mathrm{x}_{\mathrm{t}}\right)$ is to satisfy the inequalities in (9). However, now we need to ask: at what level of software are the efficiency of the new and old computers compared? In (9), we considered the software available at either $\mathrm{s}_{\mathrm{t}-1}$ or $s_{t}$. In the dynamic model, however, the characteristics chosen in (17) are optimal for the future level of software $\widetilde{s}_{t}$. This can be expected to impact the form of the inequalities in (9), as is confirmed by the following result:

\section{Proposition 2}

Suppose that computer services are given by the translog function (16) and characteristics are chosen optimally as in (17). Then under Assumption 1 (or 2), the constant-quality price ratios defined in (10) (or 11, respectively) provide the bounds:

$$
\mathrm{P}^{0}\left(\mathrm{p}_{\mathrm{t}-1}, \mathrm{p}_{\mathrm{t}}, \mathrm{x}_{\mathrm{t}-1}, \mathrm{x}_{\mathrm{t}}\right) \geq \frac{\mathrm{p}_{\mathrm{t}} / \mathrm{f}^{\ell}\left(\mathrm{x}_{\mathrm{t}}, \tilde{\mathrm{s}}_{\mathrm{t}}\right)}{\mathrm{p}_{\mathrm{t}-1} / \mathrm{f}^{\ell}\left(\mathrm{x}_{\mathrm{t}-1}, \tilde{\mathrm{s}}_{\mathrm{t}}\right)},
$$

and,

$$
\mathrm{P}^{1}\left(\mathrm{p}_{\mathrm{t}-1}, \mathrm{p}_{\mathrm{t}}, \mathrm{x}_{\mathrm{t}-1}, \mathrm{x}_{\mathrm{t}}\right) \leq \frac{\mathrm{p}_{\mathrm{t}} / \mathrm{f}^{\ell}\left(\mathrm{x}_{\mathrm{t}}, \widetilde{\mathrm{s}}_{\mathrm{t}-1}\right)}{\mathrm{p}_{\mathrm{t}-1} / \mathrm{f}^{\ell}\left(\mathrm{x}_{\mathrm{t}-1}, \widetilde{\mathrm{s}}_{\mathrm{t}-1}\right)} .
$$

The constant-quality price ratios $\mathrm{P}^{0}$ and $\mathrm{P}^{1}$ appearing on the left of (18) are similar to current BLS practice, while the expressions on the right of (18) are the true change in the price of 
computer services. So this result shows that BLS methods provides valid bound to the true change in the price of computer services when period $\mathrm{t}-1$ and $\mathrm{t}$ machines are both evaluated at the same average future level of software. It is worth stressing that these bounds (like those in Proposition 1) are an economic property, and depend on optimizing behavior, i.e. on the firstorder condition (17) as well as the concavity properties in Assumption 1 or 2. In our empirical work we shall evaluate these bounds by computing the quality-adjusted price ratios on the left of (18) and estimating the production function $\mathrm{f}^{\ell}\left(\mathrm{x}_{\mathrm{t}}, \widetilde{\mathrm{s}}_{\mathrm{t}}\right)$ that appears on the right. We will find periods in the sample where the bounds do not hold, which can arise due to non-optimizing behavior or due to mis-measurement of the production function.

Setting aside the empirical validity of the bounds in (18), however, there is another question we can ask about Proposition 2, and that concerns the level of software used to evaluated true ratio of services price on the right of (18). Suppose that instead of evaluating the firms' production functions $\mathrm{f}^{\ell}\left(\mathrm{x}_{\mathrm{t}}, \tilde{\mathrm{s}}_{\mathrm{t}}\right)$ with future software as in (18), our goal instead is to evaluate it with current software ( $\mathrm{s}_{\mathrm{t}}$ or $\mathrm{s}_{\mathrm{t}-1}$ ), as on the right of (9). Thus, when the BLS producer price index for computers is used to deflate computer input purchases by firms, we are assuming that the price index accurately reflects cost of purchasing services at the current level of software. Therefore, we are interested in knowing whether BLS procedures-like the construction of the constant-quality price ratios $\mathrm{P}^{0}$ and $\mathrm{P}^{1}$ - provide bounds to the true services price ratio at current levels of software.

To answer this question, we introduce additional restrictions on the production function $\mathrm{f}^{\ell}\left(\mathrm{x}_{\mathrm{t}}, \mathrm{s}_{\mathrm{t}}\right)$. In particular, suppose that characteristics and software are complements in the sense that $\partial^{2} \ln \mathrm{f}^{\ell} / \partial \mathrm{x}_{\mathrm{t}} \partial \mathrm{s}_{\mathrm{t}}=\Gamma>0$. To interpret this condition, note that from the first-order condition 
(9) we have:

$$
\frac{d x_{t}}{d s_{t}}=-\left[\frac{\partial^{2} \ln f}{\partial x_{t}^{2}}\right]^{-1}\left[\frac{\partial^{2} \ln f}{\partial x_{t} \partial s_{t}}\right]=-A^{-1} \Gamma
$$

Assuming that $\ln \mathrm{f}^{\ell}\left(\mathrm{x}_{\mathrm{t}}, \mathrm{s}_{\mathrm{t}}\right)$ is strictly concave in $\mathrm{x}_{\mathrm{t}}$ (slight stronger than Assumption $\left.1 \mathrm{~b}\right)$ so that $\mathrm{A}^{-1}$ is negative definite, with $\Gamma>0$ we obtain:

$$
\Gamma^{\prime} \frac{\mathrm{dx}_{\mathrm{t}}}{\mathrm{ds}_{\mathrm{t}}}=-\Gamma^{\prime} \mathrm{A}^{-1} \Gamma \text { is positive definite. }
$$

Thus, with $\Gamma>0$ increases in software will tend to increase the characteristics (in the sense that pre-multiplying $\mathrm{dx}_{\mathrm{t}} / \mathrm{ds}_{\mathrm{t}}$ by the positive matrix $\Gamma$ yields a positive definite matrix). In this sense, characteristics and software are complements.

With this assumption we have the following extension of Proposition 2:

\section{Corollary}

If $\Gamma>0$, then the bounds in (18) become:

$$
\mathrm{P}^{0}\left(\mathrm{p}_{\mathrm{t}-1}, \mathrm{p}_{\mathrm{t}}, \mathrm{x}_{\mathrm{t}-1}, \mathrm{x}_{\mathrm{t}}\right) \geq \frac{\mathrm{p}_{\mathrm{t}} / \mathrm{f}^{\ell}\left(\mathrm{x}_{\mathrm{t}}, \widetilde{\mathrm{s}}_{\mathrm{t}}\right)}{\mathrm{p}_{\mathrm{t}-1} / \mathrm{f}^{\ell}\left(\mathrm{x}_{\mathrm{t}-1}, \widetilde{\mathrm{s}}_{\mathrm{t}}\right)} \leq \frac{\mathrm{p}_{\mathrm{t}} / \mathrm{f}^{\ell}\left(\mathrm{x}_{\mathrm{t}}, \mathrm{s}_{\mathrm{t}}\right)}{\mathrm{p}_{\mathrm{t}-1} / \mathrm{f}^{\ell}\left(\mathrm{x}_{\mathrm{t}-1}, \mathrm{~s}_{\mathrm{t}}\right)},
$$

and,

$$
\mathrm{P}^{1}\left(\mathrm{p}_{\mathrm{t}-1}, \mathrm{p}_{\mathrm{t}}, \mathrm{x}_{\mathrm{t}-1}, \mathrm{x}_{\mathrm{t}}\right) \leq \frac{\mathrm{p}_{\mathrm{t}} / \mathrm{f}^{\ell}\left(\mathrm{x}_{\mathrm{t}}, \widetilde{\mathrm{s}}_{\mathrm{t}-1}\right)}{\mathrm{p}_{\mathrm{t}-1} / \mathrm{f}^{\ell}\left(\mathrm{x}_{\mathrm{t}-1}, \tilde{\mathrm{s}}_{\mathrm{t}-1}\right)} \leq \frac{\mathrm{p}_{\mathrm{t}} / \mathrm{f}^{\ell}\left(\mathrm{x}_{\mathrm{t}}, \mathrm{s}_{\mathrm{t}-1}\right)}{\mathrm{p}_{\mathrm{t}-1} / \mathrm{f}^{\ell}\left(\mathrm{x}_{\mathrm{t}-1}, \mathrm{~s}_{\mathrm{t}-1}\right)}
$$

Conversely, if $\Gamma<0$ then the second inequalities appearing in (20a) and (20b) are reversed.

The first inequalities appearing in (20) are identical to those in (18), of course, so the new results in the Corollary are the second inequalities. From (20), it is evident that BLS procedures do not provide bounds to the true services price ratio evaluated at the current (period $t$ - 1 or $t$ ) fixed level of software. When $\Gamma>0$, the constant-quality price ratio $\mathrm{P}^{0}$ on the left of (20a) is no 
longer an upper bound for the change in the price of services on the right. While the price ratio $\mathrm{P}^{1}$ on the left of (20b) is a lower bound for the change in the price of services, there is nothing that guarantees that this bound will be tight: it could be significantly less than the true change in the prices of computer services. When $\Gamma<0$ then the second inequalities in (20) are reversed, but with mixed signs within $\Gamma$ we will generally have to evaluate the production functions $\mathrm{f}^{\ell}\left(\mathrm{x}_{\mathrm{t}}, \widetilde{\mathrm{s}}_{\mathrm{t}}\right)$ and $\mathrm{f}^{\ell}\left(\mathrm{x}_{\mathrm{t}}, \mathrm{s}_{\mathrm{t}}\right)$ to know how the true ratio of services price compares at the future and current levels of software. ${ }^{6}$

As noted in the previous section, when we evaluate the quality-adjusted price ratios $\mathrm{P}^{0}$ and $\mathrm{P}^{1}$ at the mean level of characteristics each year (and corresponding expected price), we obtain the hedonic Laspeyres and Paasche indexes, respectively. These are the bounds on the left of (20), and the Laspeyres index is currently constructed by the BLS. Likewise, we can evaluate the production functions appearing in (20) at the mean level of characteristics each year to obtain indexes of the true price of computer services. As in (20) these indexes can be constructed with either future levels of software $\left(\tilde{\mathrm{s}}_{\mathrm{t}-1}\right.$ or $\left.\tilde{\mathrm{s}}_{\mathrm{t}}\right)$ or current levels of software $\left(\mathrm{s}_{\mathrm{t}-1}\right.$ or $\mathrm{s}_{\mathrm{t}}$. The precise construction of these indexes is discussed in the next section.

\section{Measurement of Computer Price Indexes}

Our interest is in estimating $\Gamma$ and other parameters of the translog services function (16), and use these to construct the true price ratio of computer services, measured with constant software $s_{t-1}$ or $s_{t}$ as on the right of (20). These time-series of true services prices can then be compared to the constant-quality price ratios $\mathrm{P}^{0}$ and $\mathrm{P}^{1}$ in (11). If there is a significant difference

\footnotetext{
6 Note that the second inequalities appearing in (20) are numerical rather than economic properties: once the sign pattern of $\Gamma$ is established by estimation, if it has mostly positive elements then the true price index with current software should exceed that with future software.
} 
between the change in the true price ratio and these constant-quality price ratios, this will indicate the potential bias in current BLS procedures.

The estimation will rely on a two-step procedure. In the first step we estimate conventional hedonic regressions on desktop PC's from monthly data. The data are from the $P C$ Data Retail Hardware Monthly Report and report quantities, average monthly prices and a number of machine characteristics for desktop computers. These data run from August 1997 to December 1999. ${ }^{7}$ We augment these data with desktop computer ads from PC Magazine; these data cover April 1999 to September 2001, but have fewer observations per month. Following Benkard and Bajari (2003), for each machine in our data, we collected processor benchmark data from The CPU Scorecard. The benchmark data reduce the complex interaction between a processors type and speed to a single index measuring performance. In addition to the processor benchmark, we include the amount of memory, the size of the hard drive and a number of indicator variables in the hedonic regressions. These indicator variables are: whether the computer has a CD player, sound card, Zip drive, network card, LCD monitor and whether it has SCSI hard drives. In addition, we treat the computer's factory installed operating system as a characteristic in the hedonic regressions. The summary statistics for prices and computer characteristics are reported in Table 1, while Table 2 reports the correlation matrix for the variables.

We estimate the semi-log form:

$$
\ln \mathrm{p}_{\mathrm{it}}=\alpha_{\mathrm{t}}+\beta_{\mathrm{t}}{ }^{\prime} \mathrm{x}_{\mathrm{it}}+\varepsilon_{\mathrm{it}}, \quad \mathrm{i}=1, \ldots, \mathrm{N} ; \mathrm{t}=1, \ldots, \mathrm{T},
$$

where $\mathrm{i}=1, \ldots, \mathrm{N}$ denotes individual personal computers (not necessarily available each period), and $t=1, \ldots, T$ denotes months from August 1997 to September 2001. Using these monthly

\footnotetext{
7 We thank Lanier Benkard for providing these data.
} 
hedonic regressions, we construct the change in constant-quality prices from (11) as:

$$
\begin{aligned}
& \ln \mathrm{P}_{\mathrm{i}}^{0}=\ln \mathrm{p}_{\mathrm{it}}-\ln \mathrm{p}_{\mathrm{it}-1}-\hat{\beta}_{\mathrm{t}}{ }^{\prime}\left(\mathrm{x}_{\mathrm{it}}-\mathrm{x}_{\mathrm{it}-1}\right), \\
& \ln \mathrm{P}_{\mathrm{i}}^{1}=\ln \mathrm{p}_{\mathrm{it}}-\ln \mathrm{p}_{\mathrm{it}-1}-\hat{\beta}_{\mathrm{t}-1}{ }^{\prime}\left(\mathrm{x}_{\mathrm{it}}-\mathrm{x}_{\mathrm{it}-1}\right) .
\end{aligned}
$$

As discussed in section 3, we follow Berndt and Rappaport (2001, p. 270) and construct the hedonic Laspeyres and Paasche price indexes by evaluating (22a) and (22b) using the mean value of characteristics over the models available each period, $\bar{x}_{t-1}$ and $\bar{x}_{t}$, and the prices $\ln \overline{\mathrm{p}}_{\mathrm{t}} \equiv \hat{\alpha}_{\mathrm{t}}+\hat{\beta}_{\mathrm{t}}{ }^{\prime} \overline{\mathrm{x}}_{\mathrm{t}}, \mathrm{t}=1, \ldots, \mathrm{T}$. Substituting these into (22), we obtain:

Change in hedonic Laspeyres index $=\left[\hat{\alpha}_{t}-\hat{\alpha}_{t-1}+\left(\hat{\beta}_{t}-\hat{\beta}_{t-1}\right)^{\prime} \bar{x}_{t-1}\right]$,

Change in hedonic Paasche index $=\left[\hat{\alpha}_{t}-\hat{\alpha}_{t-1}+\left(\hat{\beta}_{t}-\hat{\beta}_{t-1}\right)^{\prime} \bar{x}_{t}\right]$.

The average of these is:

Change in hedonic Fisher index $=\left[\hat{\alpha}_{t}-\hat{\alpha}_{t-1}+\frac{1}{2}\left(\hat{\beta}_{t}-\hat{\beta}_{t-1}\right)^{\prime}\left(\bar{x}_{t}+\bar{x}_{t-1}\right)\right]$.

These log changes can be cumulated to obtain the levels of each index.

In the second-step, we make use of actual purchases of desktop PC's by each academic or administrative department at the University of California, Davis, which we index by $\ell=1, \ldots, \mathrm{L}$. These data cover July 1997 through September of 2001 and report the machine characteristics for all purchases by each academic and administrative department. Table 3 reports the summary statistics for these data. ${ }^{8}$ The UC Davis data is used to estimate the parameters of the translog production function (16), by using the first-order condition (17). Using (16) and (21), the (17)

\footnotetext{
8 We do not use the purchase price for the UC Davis dataset because it includes peripheral equipment, but we report this price in Table 3 for completeness.
} 
becomes:

$$
\hat{\beta}_{\mathrm{t}}=\mathrm{a}_{\ell}+\mathrm{Ax}_{\mathrm{i} \ell \mathrm{t}}+\sum_{\tau=0}^{\overline{\mathrm{T}}} \theta_{\mathrm{t}, \tau} \Gamma \mathrm{s}_{\mathrm{t}+\tau}+\mathrm{u}_{\mathrm{it}}, \quad \mathrm{i}=1, \ldots, \mathrm{N} ; \ell=1, \ldots, \mathrm{L} ; \mathrm{t}=1, \ldots, \mathrm{T}
$$

In this notation, $\mathrm{x}_{\mathrm{i} \ell \mathrm{t}}$ denotes a computer of type $\mathrm{i}$ purchased by department $\ell$ in month $\mathrm{t}$. Notice that (25) is a vector of equations, one for each characteristic. From (16b), the weights $\theta_{\mathrm{t}, \tau}$ sum to unity over $\tau=0,1, . ., \overline{\mathrm{T}}$, where $\overline{\mathrm{T}}$ is the numbers of periods that a machine purchased at time $\mathrm{t}$ is used. For simplicity in the estimation we set $\overline{\mathrm{T}}$ at 3 years.

Having obtained the estimates of $A$ and $\Gamma$ from (25), we can use these to construct the true change in computer services price, using the software at date $\mathrm{t}-1$ :

$$
\begin{aligned}
& \ln \left[\frac{\mathrm{p}_{\mathrm{it}} / \mathrm{f}^{\ell}\left(\mathrm{x}_{\mathrm{it}}, \mathrm{s}_{\mathrm{t}-1}\right)}{\mathrm{p}_{\mathrm{it}-1} / \mathrm{f}^{\ell}\left(\mathrm{x}_{\mathrm{it}-1}, \mathrm{~s}_{\mathrm{t}-1}\right)}\right] \\
& =\ln \mathrm{p}_{\mathrm{it}}-\left(\hat{\mathrm{a}}_{\ell}{ }^{\prime} \mathrm{x}_{\mathrm{it}}+\frac{1}{2} \mathrm{x}_{\mathrm{it}}{ }^{\prime} \hat{\mathrm{A}} \mathrm{x}_{\mathrm{it}}+\mathrm{x}_{\mathrm{it}}{ }^{\prime} \hat{\Gamma} \mathrm{s}_{\mathrm{t}-1}\right) \\
& \quad-\ln \mathrm{p}_{\mathrm{it}-1}+\left(\hat{\mathrm{a}}_{\ell} \mathrm{x}_{\mathrm{it}-1}+\frac{1}{2} \mathrm{x}_{\mathrm{it}-1}{ }^{\prime} \hat{\mathrm{A}} \mathrm{x}_{\mathrm{it}-1}+\mathrm{x}_{\mathrm{it}-1}{ }^{\prime} \hat{\Gamma} \mathrm{s}_{\mathrm{t}-1}\right)
\end{aligned}
$$

which follows from (16). To simplify (26), we can use the Quadratic Identity of Diewert (1978, pp. 118), which states that the difference between the quadratic functions $\ln \mathrm{f}^{\ell}\left(\mathrm{x}_{\mathrm{it}}, \mathrm{s}_{\mathrm{it}-1}\right)$ and $\ln \mathrm{f}^{\ell}\left(\mathrm{x}_{\mathrm{it}-1}, \mathrm{~s}_{\mathrm{it}-1}\right)$ equals:

$$
\ln \mathrm{f}^{\ell}\left(\mathrm{x}_{\mathrm{it}}, \mathrm{s}_{\mathrm{it}-1}\right)-\ln \mathrm{f}^{\ell}\left(\mathrm{x}_{\mathrm{it}-1}, \mathrm{~s}_{\mathrm{it}-1}\right)=\frac{1}{2}\left[\frac{\partial \ln \mathrm{f}^{\ell}}{\partial \mathrm{x}_{\mathrm{it}}}+\frac{\partial \ln \mathrm{f}^{\ell}}{\partial \mathrm{x}_{\mathrm{it}-1}}\right]^{\prime}\left(\mathrm{x}_{\mathrm{it}}-\mathrm{x}_{\mathrm{it}-1}\right),
$$

where both derivatives are evaluated at $\mathrm{s}_{\mathrm{it}-1}$. Let us denote the estimates of these derivatives by:

$$
\hat{\hat{\beta}}_{\mathrm{t}-1}^{\ell} \equiv \frac{1}{2}\left[\frac{\partial \ln \mathrm{f}^{\ell}}{\partial \mathrm{x}_{\mathrm{it}}}+\frac{\partial \ln \mathrm{f}^{\ell}}{\partial \mathrm{x}_{\mathrm{it}-1}}\right]=\hat{\mathrm{a}}_{\ell}+\frac{1}{2} \hat{\mathrm{A}}\left(\mathrm{x}_{\mathrm{it}}+\mathrm{x}_{\mathrm{it}-1}\right)+\hat{\Gamma} \mathrm{s}_{\mathrm{it}-1},
$$


which follows from the definition of the translog function in (16).

Then substituting (28) and (29) into (26), we can alternatively express the true change in services price, using the firms' production functions, as:

$$
\ln \left[\frac{\mathrm{p}_{\mathrm{it}} / \mathrm{f}^{\ell}\left(\mathrm{x}_{\mathrm{it}}, \mathrm{s}_{\mathrm{t}-1}\right)}{\mathrm{p}_{\mathrm{it}-1} / \mathrm{f}^{\ell}\left(\mathrm{x}_{\mathrm{it}-1}, \mathrm{~s}_{\mathrm{t}-1}\right)}\right]=\left[\ln \mathrm{p}_{\mathrm{it}}-\ln \mathrm{p}_{\mathrm{it}-1}-\hat{\hat{\beta}}_{\mathrm{t}-1}^{\ell}{ }^{\prime}\left(\mathrm{x}_{\mathrm{it}}-\mathrm{x}_{\mathrm{it}-1}\right)\right]
$$

This formula applies to a single machine. To obtain an index of the true services price we evaluate (26') at the mean value of characteristics in each period. We also use these mean characteristics to evaluate $\hat{\beta}_{t-1}^{\ell}$ in (28), and to evaluate the prices $\ln \overline{\mathrm{p}}_{\mathrm{t}} \equiv \hat{\alpha}_{\mathrm{t}}+\hat{\beta}_{\mathrm{t}}{ }^{\prime} \overline{\mathrm{x}}_{\mathrm{t}}$, also using the mean $\mathrm{a}_{\ell}$ across departments. This gives us the index of the true change in services price:

Change in true services price with software $\mathrm{s}_{\mathrm{t}-1}$

$$
=\left[\alpha_{t}+\hat{\beta}_{i t}^{\prime} \bar{x}_{t}-\alpha_{t-1}-\hat{\beta}_{i t-1}{ }^{\prime} \bar{x}_{t-1}-\hat{\beta}_{t-1}^{\ell}{ }^{\prime}\left(\bar{x}_{t}-\bar{x}_{t-1}\right)\right] .
$$

Similarly, we can construct the true index using software at date t. Let $\hat{\beta}_{\mathrm{t}}^{\ell}$ denote exactly the same expression as in (28) but using $\mathrm{s}_{\mathrm{t}}$ rather than $\mathrm{s}_{\mathrm{t}-1} \cdot{ }^{9}$ Then taking the average of (29) evaluated with $\hat{\hat{\beta}}_{\mathrm{t}-1}^{\ell}$ and $\hat{\hat{\beta}}_{\mathrm{t}}^{\ell}$, we obtain a Fisher-type true index:

Change in true services price with current software $\frac{1}{2}\left(\mathrm{~s}_{\mathrm{t}-1}+\mathrm{s}_{\mathrm{t}}\right)$

$$
=\left[\alpha_{t}+\hat{\beta}_{i t}{ }^{\prime} \bar{x}_{t}-\alpha_{t-1}-\hat{\beta}_{i t-1}{ }^{x} \bar{x}_{t-1}-\frac{1}{2}\left(\hat{\beta}_{t-1}^{\ell}+\hat{\beta}_{t}^{\ell}\right)^{\prime}\left(\bar{x}_{t}-\bar{x}_{t-1}\right)\right]
$$

Finally, we can evaluate the firms' production functions using future software $\widetilde{s}_{t}$, defined

\footnotetext{
9 Again, we evaluate $\hat{\hat{\beta}}_{\mathrm{t}}^{\ell}$ at the mean level of characteristics and the mean level of $\mathrm{a}_{\ell}$ across departments.
} 
in (17b), rather than current software $\mathrm{s}_{\mathrm{t}}$. Let $\widetilde{\beta}_{\mathrm{t}-1}^{\ell}$ denote exactly the same expression as in (28) but using $\widetilde{\mathrm{s}}_{\mathrm{t}-1}$ rather than $\mathrm{s}_{\mathrm{t}-1}$, while $\widetilde{\beta}_{\mathrm{t}}^{\ell}$ uses $\widetilde{\mathrm{s}}_{\mathrm{t}}$. Then the Fisher-type true index using the future levels of software is:

Change in true services price with future software $\frac{1}{2}\left(\widetilde{\mathrm{s}}_{\mathrm{t}-1}+\widetilde{\mathrm{s}}_{\mathrm{t}}\right)$

$$
=\left[\alpha_{t}+\hat{\beta}_{i t}^{\prime} \bar{x}_{t}-\alpha_{t-1}-\hat{\beta}_{i t-1}{ }^{\prime} \bar{x}_{t-1}-\frac{1}{2}\left(\widetilde{\beta}_{t-1}^{\ell}+\widetilde{\beta}_{t}^{\ell}\right)^{\prime}\left(\bar{x}_{t}-\bar{x}_{t-1}\right)\right] \text {. }
$$

We can compare these true service price indexes, obtained from the firms' production functions, to the Laspeyres and Paasche bounds from (23) or the hedonic Fisher index in (24). Notice that the difference between the change in the true services price using current software in (30) and the hedonic Fisher index in (24) can be simplified as:

Change in true services price with current software - hedonic Fisher index

$$
=\sum_{\mathrm{i}=1}^{\mathrm{N}} \frac{1}{2}\left[\left(\hat{\beta}_{\mathrm{t}-1}+\hat{\beta}_{\mathrm{t}}\right)-\left(\hat{\hat{\beta}}_{\mathrm{t}-1}^{\ell}+\hat{\hat{\beta}}_{\mathrm{t}}^{\ell}\right)\right]^{\prime}\left(\overline{\mathrm{x}}_{\mathrm{t}}-\overline{\mathrm{x}}_{\mathrm{t}-1}\right) .
$$

Likewise, the difference between (31) and (24) has the same form as (32), but using $\widetilde{\beta}_{t-1}$ and $\widetilde{\beta}_{t}$ rather than $\hat{\beta}_{t-1}$ and $\hat{\beta}_{t}$. With characteristics growing over time, expression (32) will be positive provided that $\frac{1}{2}\left(\hat{\beta}_{\mathrm{t}-1}+\hat{\beta}_{\mathrm{t}}\right)>\frac{1}{2}\left(\hat{\hat{\beta}}_{\mathrm{t}-1}^{\ell}+\hat{\hat{\beta}}_{\mathrm{t}-1}^{\ell}\right)$. This condition states that the typically estimated hedonic coefficients, $\hat{\beta}_{\mathrm{t}-1}$ and $\hat{\beta}_{\mathrm{t}}$, exceed the true value of these characteristics to the user with software at time $\mathrm{t}-1$ and $\mathrm{t}, \hat{\hat{\beta}}_{\mathrm{t}-1}^{\ell}$ and $\hat{\hat{\beta}}_{\mathrm{t}}^{\ell}$. This corresponds to our intuition that users may "overbuy" characteristics such as RAM and hard disk space, because they will become more valuable at future states of software. 


\section{Empirical Results}

\subsection{Hedonic Regressions}

To conserve on space, we do not report each of the coefficients from the monthly hedonic equations, but Table 4 summarizes the coefficients for the included characteristics. The typical $\mathrm{R}^{2}$ from the hedonic regression is roughly 0.60 , but ranges from 0.13 to 0.90 . It is important to note that the value of the characteristics captured by indicator variables may not be identified in a given month, since in some months all of the computers in the sample have or do not have the given characteristic. In general, the mean coefficient for each of the characteristics is positive. The exceptions are the indicator variables for whether the computer has a CD or a sound card; the coefficients associated with these characteristics are quite noisy.

Figures 1 through 3 track the monthly hedonic coefficients for the processor speed, RAM and hard drive size variables and provide 95 percent confidence intervals for the point estimates. We focus on these three characteristics because their coefficients are identified in every month and they are the main determinants of a computer's price. ${ }^{10}$ Each of the coefficients display a general downward trend as characteristic prices fell during our sample; a regression of the coefficient on a linear time confirms this and yields negative and significant coefficient for each of the variables. The processor speed coefficient displays a sharp increase between May 1999 and June 1999. We have verified with cpuscorecard.com that this is not due to a change in the benchmark definition. In addition, the hard drive coefficient exhibits a sharp decline between August 1997 and August 1998. Finally, the processor speed and RAM coefficients display a reduction in precision later in the sample. This is due to smaller sample sizes for the $P C$

\footnotetext{
${ }^{10}$ These three variables alone account for, on average, over 80 percent of the explained variation from the hedonic regressions.
} 
Magazine price data compared to the PC Data Retail Hardware Monthly Report data. ${ }^{11}$

\subsection{Departmental Production Functions}

A key component for the decision process of the consumer or firm is the expected software quality; admittedly, this is difficult to quantify. We discussed a number of potential measures of quality with software programmers and settled on the recommended hard drive space for both Microsoft Windows and Microsoft Word. Increases in software require additional hard-drive capacity and will be reflected in the recommended hard drive capacities of the programs. ${ }^{12}$ This measure displays a general upward trend as both Office and Windows have added features. As with the dependent variable in the second stage, our software quality measure exhibits time series variation and is identified from the change in the average characteristics of purchased computers over time.

Estimating (25) requires including the expected movements in software quality over the lifetime of the machine. Rather than modeling the primitives of these expectations, we include the actual movements of our software quality measure. To capture the uncertainty associated with these expectations, we assume an artificially high discount rate, $2 \%$ per month, in (17b). This implies that departments place more weight on the expectations of software quality during the earlier months of a computer's lifetime. The high discount rate suggests they do so because there is less uncertainty regarding quality early in the lifetime of the machine.

We focus on the first order condition (25) for three characteristics: processor speed, hard drive size and RAM. We estimate the three first order conditions simultaneously via least

\footnotetext{
${ }^{11}$ In our second stage regressions, we report heteroskedastic consistent standard errors to account for this.

12 The required memory was also a candidate. However, the programmers that we spoke to were under the impression that software engineers now "waste" more memory than in previous periods, whereas this is not the case for hard-drive space. Including the recommended RAM levels does not qualitatively change the results.
} 
squares and impose symmetry in the matrix A of the production function. ${ }^{13}$ The results from the second stage regressions are reported in Table 5. The results with respect to the quadratic portion of the production function (the A matrix) are largely consistent with our economic intuition. The diagonal elements are negative suggesting decreasing returns to speed, hard drive capacity and memory. Two of the three off-diagonals are positive, the exception being the crossderivative of RAM and hard drive capacity.

The results with respect to the software measures are somewhat puzzling. Increases in the hard disk requirements of Microsoft Office tend to increase the marginal product of the computer characteristics ( $\Gamma_{\text {Office }}>0$ in two out of three columns of Table 5). This means that Office and the hardware characteristics are complements, in the sense that increases in Office requirements leads to higher purchases of speed, RAM, and hard disk size. In other words, departments "over purchase" the characteristics in the current period to compensate for future increases in Office software requirements; this is consistent with our priors. In contrast, the coefficients associated with Windows hard disk requirements tend to be negative $\left(\Gamma_{\text {Windows }}<0\right.$ in two out of three columns), which suggests that departments reduce their demand for hardware characteristics in response to an increase in Windows hard disk requirements.

One possible explanation for this finding is that departments do not increase the characteristics of a computer purchase in response to expected changes in Windows, but instead shorten the time period in which the computer is held. That is, if departments expect increases in Windows quality in the near future, they reduce the characteristics of the current purchase in expectation of buying a computer when the new version of Windows was released. This is consistent with anecdotal evidence that suggests that consumers do not upgrade Windows as

\footnotetext{
${ }^{13}$ Individual tests on the symmetry of the off-diagonals fail to reject equality.
} 
much as Office, instead implicitly "upgrading" by purchasing a new machine, and that quality changes of Windows appear to be more discrete than quality changes of Office. Behavior of this type is outside our model, however, because the time a computer is held is taken as exogenous. An alternative, statistical explanation for $\Gamma_{\text {Windows }}<0$ is that it is capturing the overall negative trend in the hedonic coefficients, which are the dependent variable in (25).

\subsection{Price Indexes}

Given the estimates from the second stage, we calculate five price indexes. The first three are the hedonic Laspeyres, Paasche and Fisher, in (23)-(24); the fourth is the true services price with current software $\frac{1}{2}\left(\mathrm{~s}_{\mathrm{t}-1}+\mathrm{s}_{\mathrm{t}}\right)$, in (28), which we refer to as the "production function, current software;" and the fifth is the true services price with future software $\frac{1}{2}\left(\tilde{\mathrm{s}}_{\mathrm{t}-1}+\tilde{\mathrm{s}}_{\mathrm{t}}\right)$, which we refer to as the "production function, future software." The five price indexes are graphed in Figures 4-7 and display a number of interesting points.

First, the production function method that uses current software levels is consistently higher than the hedonic Fisher index in Figure 4, which is itself bounded quite tightly by the Laspeyres and Paasche indexes. A close examination of that figure shows that the indexes diverge immediately in the first months of our sample, however, so to control for this possibly erratic behavior, in Figure 5 we show the same five indexes but normalized at 100 in May 1998 rather than August 1997. In this case the production function index with current software is still above the hedonic Fisher index, but by the end of the sample the indexes are about equal. This means that the slower decline of the production function index in the early years (1998-1999) is offset by a faster decline of this index in later year (2000-2001), as compared to the hedonic Fisher index. 
This difference in the growth rates over the two halves of our sample can also be seen from Figures 6 and 7, where we graph the five indexes from August 1997 - July 1999 and August 1999 - September 2001, respectively. In Figure 6, the faster decline of the hedonic indexes from the production function indexes are readily apparent. This is also seen from the average annual growth rates (AAGR) reported in Table 6, where the hedonic Fisher declines at a $51 \%$ AAGR during the first half of the sample, as compared to $14 \%$ and $38 \%$ for the production function with current and future software, respectively. ${ }^{14}$ If the sample for this study had stopped in 1999, the evidence in Figure 6 and Table 6 would have led to the conclusion that the hedonic method (either the Fisher, Laspeyres or Paasche) was substantially overstating the true decline in prices as measured by the production function method with current software. This is consistent with the results of the above Corollary when $\Gamma>0$, so that software requirements and hardware are complements. ${ }^{15}$

However, this overstatement is reversed in the second half of the sample, as shown in Figure 7 and the third row of Table 6, where the hedonic Fisher index falls at a 20\% AAGR, as compared to $35 \%$ and $38 \%$ for the production function with current and future software, respectively. Evidently, both of the production function indexes are being pulled down by factors that do not influence the hedonic indexes. In 2001, the AAGR of the production function index with future software is actually above that with current software, which from the above Corollary, can occur if and only if some of the $\Gamma$ coefficients are negative. Recall that these coefficients are negative for Windows software in two of the three regressions shown in Table 5,

\footnotetext{
14 In comparison, Berndt and Rappaport (2001, p. 271) report an AAGR for the hedonic Laspeyres and Paasche indexes of $-40 \%$ and $-42 \%$, respectively, over 1994-1999, for desktop PC's.

15 The fact that the hedonic indexes are also overstating the decline in the production function index with future software is not consistent with the inequality (18a) in Proposition 2. But notice that if we exclude the first 9 months of the sample, as in Figure 6, then the hedonic indexes closely track the production function index with future software, at least through the first half of the sample.
} 
meaning that the Windows quality is a substitute rather than a complement with hardware characteristics. This puzzling finding seems to affect the production function indexes in the second half of our sample, possibly because of the especially large hard disk requirements of Windows XP and 2003. We have already suggested above that the negative $\Gamma$ coefficients on Windows may be due to our assumption of a fixed lifetime of a machine ( 3 years). We conclude by suggesting two other reasons for the slower growth rate of the hedonic indexes in the second half of our sample, as compared to the production function method.

First, we mention again that our sample used to estimate the hedonic regressions is much smaller after 2000, because it is collected from advertisements in PC Magazine rather than the PC Data Retail Hardware Monthly Report data. The somewhat erratic behavior of the hedonic coefficients after 2000, and the fact that the hedonic indexes actually increase in 2001, suggest that a large sample of computer prices and characteristics would be desirable in the second half of our sample. This might affect our results.

Setting aside this statistical concern, there is the conceptual possibility that technological improvements in the production of RAM, hard disk space and speed of machines means that these are no longer the limiting features of a computer. Rather, some computer scientists have suggested that it is the functionality of software that limit users, and not the hardware. In this case the slowdown in the fall of the hedonic computer price would be a real phenomena, and the overstatement of the "true" decline in the price of computer services price would be history. Under this scenario, the benefits to users would need to be evaluated using both hardware and software. While we have incorporated software in this paper, it has been more as a complement (or substitute) for hardware, but not as an independent feature affecting the functionality of machines. Assessing this aspect of software is one important area for future research. 


\section{Conclusions}

In this paper we show that conventional hedonic methods may overstate the price decline of personal computers, which are treated here as a durable good. Optimizing agents that anticipate increases in software quality will "overbuy" the characteristics of a computer, in the sense that the purchased bundle of characteristics is not fully utilized in the first months or year that a computer is owned. Forward looking buyers equate the marginal benefit of characteristics over the lifetime of a machine to the marginal cost at the time of purchase. In this case, hedonic procedures may not provide valid bounds on the true price of computer services at the time when the new machine is purchased, with the concurrent level of software. While we focus on personal computers, our results may also apply to any durable good in which the quality of a complementary product changes over time. For example, if there are switching costs associated with bank accounts, then a consumer will establish a deposit account based on expected changes in the size of banks' ATM networks, ATMs being a strong complementary product to a deposit account. $^{16}$

Our empirical application confirms the theoretical results in the first half of our sample. Using data from UC Davis computer purchase behavior, we find that the hedonic price index constructed with BLS methods typically overstates the fall in computer prices, as compared to the true price index constructed using the users' estimated production function. Furthermore, we find that the true services prices falls faster when it is evaluated with future rather than current levels of software. However, in the second half of the sample this bias has been ameliorated and even reversed so that, depending on the starting month, the overall decline in the hedonic indexes is not that different from the true indexes that result from estimating the firms' production

\footnotetext{
${ }^{16}$ For example, Knittel and Stango (2003) estimate hedonic price regressions for banking services and find that ATM network sizes have a significant impact on prices, as does the compatibility between deposit accounts of one bank and the ATM's of another.
} 
functions over computer characteristics. This provides some empirical justification for the hedonic methods now used by BLS and BEA, despite the fact that their theoretical properties are called into question when computers are treated as a durable good and software changes.

We have suggested that one area for further research is to directly evaluate the usefulness of software in enhancing consumer benefits of personal computers. White et al (2004) provide evidence on the price declines of these software over 1984 to 2000, and note that price declines are generally greater in the later years of their sample. Conversely, Ellison and Fudenberg (2000) argue theoretically that the backwards connectivity of software packages, as well as network effects, can lead firms to develop too many upgrades resulting in a loss in social welfare. So a full evaluation of the costs and benefits of software is evidently complicated. But perhaps we have reached a point where more attention needs to be paid to software and its characteristics, and not to the declining costs of extra megahertz or gigabytes, in evaluating the productivity and welfare impact of personal computers. 


\section{$\underline{\text { Appendix }}$}

\section{Proof of Proposition 1:}

First suppose that Assumption 2 holds. The efficiency of a computer purchased in year $t$ relative to that in year $\mathrm{t}-1$, with both using the software in $\mathrm{t}$, is:

$$
\begin{aligned}
\mathrm{f}\left(\mathrm{x}_{\mathrm{t}}, \mathrm{s}_{\mathrm{t}}\right) / \mathrm{f}\left(\mathrm{x}_{\mathrm{t}-1}, \mathrm{~s}_{\mathrm{t}}\right) & \geq\left[\mathrm{f}\left(\mathrm{x}_{\mathrm{t}-1}, \mathrm{~s}_{\mathrm{t}}\right)+\mathrm{f}_{\mathrm{x}}\left(\mathrm{x}_{\mathrm{t}}, \mathrm{s}_{\mathrm{t}}\right)\left(\mathrm{x}_{\mathrm{t}}-\mathrm{x}_{\mathrm{t}-1}\right)\right] / \mathrm{f}\left(\mathrm{x}_{\mathrm{t}-1}, \mathrm{~s}_{\mathrm{t}}\right) \\
& =\left\{\mathrm{f}\left(\mathrm{x}_{\mathrm{t}-1}, \mathrm{~s}_{\mathrm{t}}\right)+\left[\mathrm{f}\left(\mathrm{x}_{\mathrm{t}}, \mathrm{s}_{\mathrm{t}}\right) / \mathrm{h}_{\mathrm{t}}\left(\mathrm{x}_{\mathrm{t}}\right)\right] \beta_{\mathrm{t}}^{\prime}\left(\mathrm{x}_{\mathrm{t}}-\mathrm{x}_{\mathrm{t}-1}\right)\right\} / \mathrm{f}\left(\mathrm{x}_{\mathrm{t}-1}, \mathrm{~s}_{\mathrm{t}}\right)
\end{aligned}
$$

where the first line follows from concavity of $\mathrm{f}\left(\mathrm{x}_{\mathrm{t}}, \mathrm{s}_{\mathrm{t}}\right)$ with $\mathrm{x}_{\mathrm{t}-1} \leq \mathrm{x}_{\mathrm{t}}$, and the second line from (6) and the definition of $\beta_{\mathrm{t}} \equiv \mathrm{h}_{\mathrm{t}}{ }^{\prime}\left(\mathrm{x}_{\mathrm{t}}\right)$. Multiplying through by $\left[\mathrm{h}_{\mathrm{t}}\left(\mathrm{x}_{\mathrm{t}}\right) / \mathrm{f}\left(\mathrm{x}_{\mathrm{t}}, \mathrm{s}_{\mathrm{t}}\right)\right]$ and rearranging terms, we obtain, $\left[\mathrm{h}_{\mathrm{t}}\left(\mathrm{x}_{\mathrm{t}}\right)-\beta_{\mathrm{t}}^{\prime}\left(\mathrm{x}_{\mathrm{t}}-\mathrm{x}_{\mathrm{t}-1}\right)\right] / \mathrm{f}\left(\mathrm{x}_{\mathrm{t}-1}, \mathrm{~s}_{\mathrm{t}}\right) \geq \mathrm{h}_{\mathrm{t}}\left(\mathrm{x}_{\mathrm{t}}\right) / \mathrm{f}\left(\mathrm{x}_{\mathrm{t}}, \mathrm{s}_{\mathrm{t}}\right)$. Then dividing by $\left[\mathrm{h}_{\mathrm{t}-1}\left(\mathrm{x}_{\mathrm{t}-1}\right) / \mathrm{f}\left(\mathrm{x}_{\mathrm{t}-1}, \mathrm{~s}_{\mathrm{t}}\right)\right]$ and using the definition of $\mathrm{P}^{0}$ in (10a), we readily obtain (9a).

The efficiency of a computer purchased in year $t$ relative to $t-1$, using the software in $t-1$, is:

$$
\begin{aligned}
\mathrm{f}\left(\mathrm{x}_{\mathrm{t}}, \mathrm{s}_{\mathrm{t}-1}\right) / \mathrm{f}\left(\mathrm{x}_{\mathrm{t}-1}, \mathrm{~s}_{\mathrm{t}-1}\right) & \leq \mathrm{f}\left(\mathrm{x}_{\mathrm{t}}, \mathrm{s}_{\mathrm{t}-1}\right) /\left[\mathrm{f}\left(\mathrm{x}_{\mathrm{t}}, \mathrm{s}_{\mathrm{t}-1}\right)-\mathrm{f}_{\mathrm{x}}\left(\mathrm{x}_{\mathrm{t}-1}, \mathrm{~s}_{\mathrm{t}-1}\right)\left(\mathrm{x}_{\mathrm{t}}-\mathrm{x}_{\mathrm{t}-1}\right)\right] \\
= & \mathrm{f}\left(\mathrm{x}_{\mathrm{t}}, \mathrm{s}_{\mathrm{t}-1}\right) /\left\{\mathrm{f}\left(\mathrm{x}_{\mathrm{t}}, \mathrm{s}_{\mathrm{t}-1}\right)-\left[\mathrm{f}\left(\mathrm{x}_{\mathrm{t}-1}, \mathrm{~s}_{\mathrm{t}-1}\right) / \mathrm{h}_{\mathrm{t}-1}\left(\mathrm{x}_{\mathrm{t}-1}\right)\right] \beta_{\mathrm{t}-1}{ }^{\prime}\left(\mathrm{x}_{\mathrm{t}}-\mathrm{x}_{\mathrm{t}-1}\right)\right\}
\end{aligned}
$$

where the first line follows from concavity of $\mathrm{f}$ with $\mathrm{x}_{\mathrm{t}-1} \leq \mathrm{x}_{\mathrm{t}}$, and the second line from (6) with $\beta_{\mathrm{t}-1} \equiv \mathrm{h}_{\mathrm{t}-1}{ }^{\prime}\left(\mathrm{x}_{\mathrm{t}-1}\right)$. Inverting this expression, multiplying by $\left[\mathrm{h}_{\mathrm{t}-1}\left(\mathrm{x}_{\mathrm{t}-1}\right) / \mathrm{f}\left(\mathrm{x}_{\mathrm{t}-1}, \mathrm{~S}_{\mathrm{t}-1}\right)\right]$ and rearranging terms, we obtain $\left[\mathrm{h}_{\mathrm{t}-1}\left(\mathrm{x}_{\mathrm{t}-1}\right)+\beta_{\mathrm{t}-1}{ }^{\prime}\left(\mathrm{x}_{\mathrm{t}}-\mathrm{x}_{\mathrm{t}-1}\right)\right] / \mathrm{f}\left(\mathrm{x}_{\mathrm{t}}, \mathrm{s}_{\mathrm{t}-1}\right) \geq \mathrm{h}_{\mathrm{t}-1}\left(\mathrm{x}_{\mathrm{t}-1}\right) / \mathrm{f}\left(\mathrm{x}_{\mathrm{t}-1}, \mathrm{~s}_{\mathrm{t}-1}\right)$. Then dividing by $\left[\mathrm{h}_{\mathrm{t}}\left(\mathrm{x}_{\mathrm{t}-1}\right) / \mathrm{f}\left(\mathrm{x}_{\mathrm{t}}, \mathrm{s}_{\mathrm{t}-1}\right)\right]$, using the definition of $\mathrm{P}^{1}$ in (10b), and inverting again we readily obtain (9b).

Now suppose that Assumption 2 holds. The log-efficiency of a computer purchased in year $t$ relative to that in year $t-1$, with both using the software in $t$, is: 


$$
\ln f\left(x_{t}, s_{t}\right)-\ln f\left(x_{t-1}, s_{t}\right) \geq \beta_{t}^{\prime}\left(x_{t}-x_{t-1}\right)
$$

which follows from concavity of $\ln f\left(x_{t}, s_{t}\right)$ with $x_{t-1} \leq x_{t}$, and (6) with $\beta_{t} \equiv h_{t}{ }^{\prime}\left(x_{t}\right) / h_{t}\left(x_{t}\right)$. Taking exponents and inverting we obtain $\mathrm{f}\left(\mathrm{x}_{\mathrm{t}-1}, \mathrm{~s}_{\mathrm{t}}\right) / \mathrm{f}\left(\mathrm{x}_{\mathrm{t}}, \mathrm{s}_{\mathrm{t}}\right) \leq \exp \left[-\beta_{\mathrm{t}}{ }^{\prime}\left(\mathrm{x}_{\mathrm{t}}-\mathrm{x}_{\mathrm{t}-1}\right)\right]$. Then it follows from the definition of $\mathrm{P}^{0}$ in (11a) that (9a) holds.

The log-efficiency of a computer purchased in year t relative to that in year $\mathrm{t}-1$, with both using the software in $\mathrm{t}-1$, is:

$$
\ln \mathrm{f}\left(\mathrm{x}_{\mathrm{t}}, \mathrm{s}_{\mathrm{t}-1}\right)-\ln \mathrm{f}\left(\mathrm{x}_{\mathrm{t}-1}, \mathrm{~s}_{\mathrm{t}-1}\right) \leq \beta_{\mathrm{t}-1}^{\prime}\left(\mathrm{x}_{\mathrm{t}}-\mathrm{x}_{\mathrm{t}-1}\right)
$$

using the concavity of $\ln \mathrm{f}\left(\mathrm{x}_{\mathrm{t}}, \mathrm{s}_{\mathrm{t}-1}\right)$ with $\mathrm{x}_{\mathrm{t}-1} \leq \mathrm{x}_{\mathrm{t}}$, and (6) with $\beta_{\mathrm{t}-1} \equiv \mathrm{h}_{\mathrm{t}-1}{ }^{\prime}\left(\mathrm{x}_{\mathrm{t}-1}\right) / \mathrm{h}_{\mathrm{t}-1}\left(\mathrm{x}_{\mathrm{t}-1}\right)$. Taking exponents and inverting we obtain $\mathrm{f}\left(\mathrm{x}_{\mathrm{t}-1}, \mathrm{~s}_{\mathrm{t}-1}\right) / \mathrm{f}\left(\mathrm{x}_{\mathrm{t}}, \mathrm{s}_{\mathrm{t}-1}\right) \geq \exp \left[-\beta_{\mathrm{t}-1}{ }^{\prime}\left(\mathrm{x}_{\mathrm{t}}-\mathrm{x}_{\mathrm{t}-1}\right)\right]$. Then it follows from the definition of $\mathrm{P}^{1}$ in $(11 \mathrm{~b})$ that $(9 \mathrm{~b})$ holds. QED

\section{Proof of Proposition 2:}

The proof of this result is identical to that of Proposition 1, where we just replace $\mathrm{s}_{\mathrm{t}-1}$ with $\widetilde{\mathrm{s}}_{\mathrm{t}-1}$ and $s_{t}$ with $\widetilde{s}_{t}$, and make use of (17a) rather than (9).

\section{Proof of the Corollary:}

The first inequalities in (20a) and (20b) are identical to those in (18a) and (18b). Taking natural logs of the second inequality in (20a), and multiplying by -1, we obtain:

$$
\ln \mathrm{f}\left(\mathrm{x}_{\mathrm{t}}, \widetilde{\mathrm{s}}_{\mathrm{t}-1}\right)-\ln \mathrm{f}\left(\mathrm{x}_{\mathrm{t}-1}, \widetilde{\mathrm{s}}_{\mathrm{t}-1}\right) \geq \ln \mathrm{f}\left(\mathrm{x}_{\mathrm{t}}, \mathrm{s}_{\mathrm{t}-1}\right)-\ln \mathrm{f}\left(\mathrm{x}_{\mathrm{t}-1}, \mathrm{~s}_{\mathrm{t}-1}\right)
$$

which can be re-written as:

$$
\int_{\mathrm{x}_{\mathrm{t}-1}}^{\mathrm{x}_{\mathrm{t}}}\left[\partial \ln \mathrm{f}\left(\mathrm{z}, \widetilde{\mathrm{s}}_{\mathrm{t}-1}\right) / \partial \mathrm{z}-\partial \ln \mathrm{f}\left(\mathrm{z}, \mathrm{s}_{\mathrm{t}-1}\right) / \partial \mathrm{z}\right] \mathrm{dz} \geq 0
$$


By the mean value theorem, the integrand can be written as $\left[\partial^{2} \ln \mathrm{f}(\mathrm{z}, \mathrm{s}) / \partial \mathrm{z} \partial \mathrm{s}\right]^{\prime}\left(\widetilde{\mathrm{s}}_{\mathrm{t}-1}-\mathrm{s}_{\mathrm{t}-1}\right)$ for some value of $s$ between $s_{t-1}$ and $\widetilde{s}_{t-1}$. This expression is non-negative because (i) $\Gamma=$ $\partial^{2} \operatorname{lnf} / \partial \mathrm{x}_{\mathrm{t}} \partial \mathrm{s}_{\mathrm{t}}>0$ by hypothesis, and (ii) $\widetilde{\mathrm{s}}_{\mathrm{t}-1} \geq \mathrm{s}_{\mathrm{t}-1}$ from (17b) and because software is growing over time from Assumption 1(b) or 2(b). Therefore, the second inequality in (20a) holds. A similar proof applies to the second inequality in (20b), and to the converse case where $\Gamma=$ $\partial^{2} \operatorname{lnf} / \partial x_{t} \partial s_{t}<0 . \quad$ QED 


\section{References}

Aizcorbe, Ana, 2004, "Semiconductor Prices in the mid-1990s: Can Mismeasurement Explain the Faster Rates of Price Decline?" presented at the American Economic Association, San Diego, January.

Berndt, Ernst R. and Neal J. Rappaport, 2001, "Price and Quality of Desktop and Mobile Personal Computers: A Quarter Century Historical Review," American Economic Review, 91(2), May, 268-273.

Benkard, C. Lanier and Patrick Bajari, 2003, "Hedonic Price Indexes with Unobserved Product Characteristics, and Application to PC's," National Bureau of Economic Research working paper no. 9980 .

Cartwright, David W., 1986, "Improved Deflation of Purchases of Computers," Survey of Current Business 66, March, 7-10.

Cole, Rosanne, Y.C. Chen, Joan A. Barquin-Stolleman, Ellen Dulberger, Nurhan Helvacian and James H. Hodge, 1986, "Quality Adjusted Price Indexes for Computers Processors and Selected Peripheral Equipment," Survey of Current Business 66, January, 41-50.

Diewert, W. Erwin, 1978, "Exact and Superlative Price Indexes," Journal of Econometrics, 4, 115-145.

Diewert, W. Erwin, 1980, "Aggregation Problems in the Measurement of Capital," in Dan Usher, ed., The Measurement of Capital, Chicago: NBER \& Univ. of Chicago, 433-528.

Diewert, W. Erwin, 2003, "Hedonic Regressions: A Consumer Theory Approach," in Robert C. Feenstra and Matthew D. Shapiro, Scanner Data and Price Indexes, Chicago: NBER and Univ. of Chicago Press, 317-347.

Ellison, Glen and Drew Fudenberg, 2000, “The Neo-Luddite's Lament: Excessive Upgrades in the Software Industry," Rand Journal of Economics, Summer, 31(2), 253-272.

Feenstra, Robert C., 1995, "Exact Hedonic Price Indexes," Review of Economics and Statistics, 78(9), 634-653

Gordon, Robert J., 2000, "Does the 'New Economy' Measure Up to the Great Inventions of the Past?" Journal of Economic Perspectives, Fall, 49-74.

Grimm, Bruce T., 1998, "Price Indexes for Selected Semiconductors," Survey of Current Business, 78, February, 8-24.

Harper, Michael J., Ernst R. Berndt and David O. Wood, 1989, "Rates of Return and Capital Aggregation Using Alternative Rental Prices," in Dale W. Jorgenson and Ralph Landau, eds. Technology and Capital Formation, Cambridge: MIT Press, 331-372. 
Harper, Michael J., 2000, “Obsolescence and the Use of Prices to Measure Inputs of High Tech Capital,” Bureau of Labor Statistics, mimeo.

Holdway, Michael, 2001, "Quality-Adjusting Computer Prices in the Producer Price Index: An Overview," Bureau of Labor Statistics, Washington, D.C., http://www.bls.gov/ppi/ppicomqa.htm.

Hulten, Charles, 1990, “The Measurement of Capital," in Ernst R. Berndt and Jack E. Triplett, eds., Fifty Years of Economic Measurement, Chicago: NBER and Univ. of Chicago, 119152.

Jorgenson, Dale W. and Kevin J. Stiroh, 2000, "Raising the Speed Limit: U.S. Economic Growth in the Information Age," Brookings Papers on Economic Activity, 31(1), forthcoming.

Knittel, Christopher R. and Victor Stango, 2003, "Compatibility and Pricing with Indirect Network Effects: Evidence from ATMs," UC Davis, mimeo.

Moulton, Brendt R., 2001, “The Expanding Role of Hedonic Methods in the Official Statistics of the United States," Bureau of Economic Analysis, Department of Commerce, mimeo.

Oliner, Stephen D., 1993, "Constant-Quality Price Change, Depreciation, and Retirement of Mainframe Computers," in Murray F. Foss, Marilyn E. Manser and Allan H. Young, Price Measurements and Their Uses, Chicago: NBER and Univ. of Chicago, 19-61.

Oliner, Stephen D. and Daniel E. Sichel, 2000, "The Resurgence of Growth in the Late 1990s: Is Information Technology the Story?" Journal of Economic Perspectives, Fall, 3-22.

Pakes, Ariel, 2003, “A Reconsideration of Hedonic Price Indexes with an Application to PC's," American Economic Review, December, 1578-1596.

Rosen, Sherwin, 1974, "Hedonic Prices and Implicit Markets: Product Differentiation in Pure Competition," Journal of Political Economy, 34-55.

Triplett, Jack E., 1986. "The Economic Interpretation of Hedonic Methods, " Survey of Current Business 66, January, 49-52.

Triplett, Jack E., 1999, "The Solow Computer Paradox: What do Computers do to Productivity?" Canadian Journal of Economics, 32(2), April, 309-334.

White, Alan G., Jaison R. Abel, Ernst R. Berndt and Cory W. Monroe, 2004, "Hedonic Price Indexes for Personal Computer Operating Systems and Productivity Suites," NBER working paper no. 10427 
Processor Speed Hedonic Coefficients

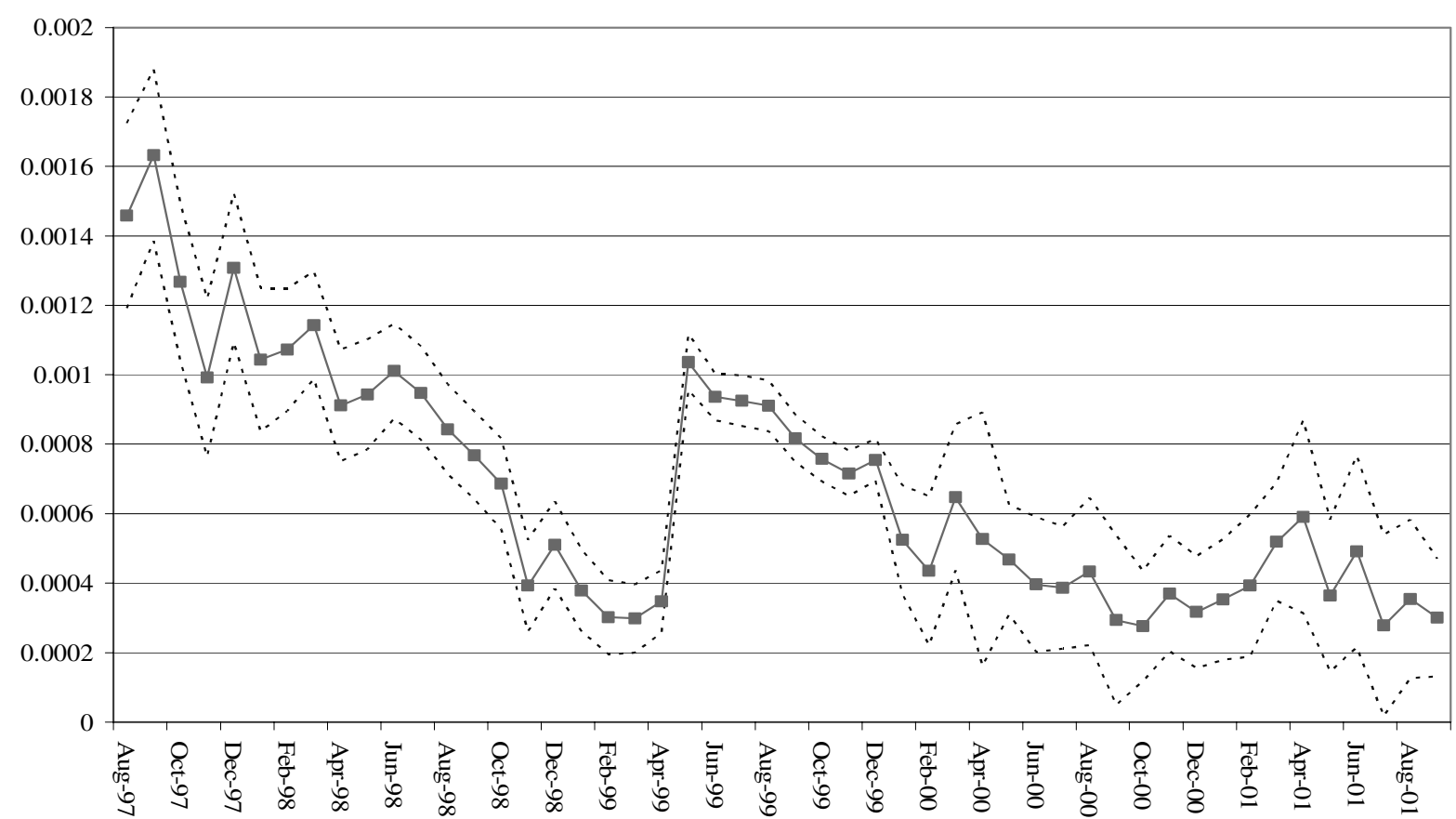

Figure 1: Plot of the Monthly Processor Speed Hedonic Coefficients for Semi-Log Model 
RAM Hedonic Coefficients

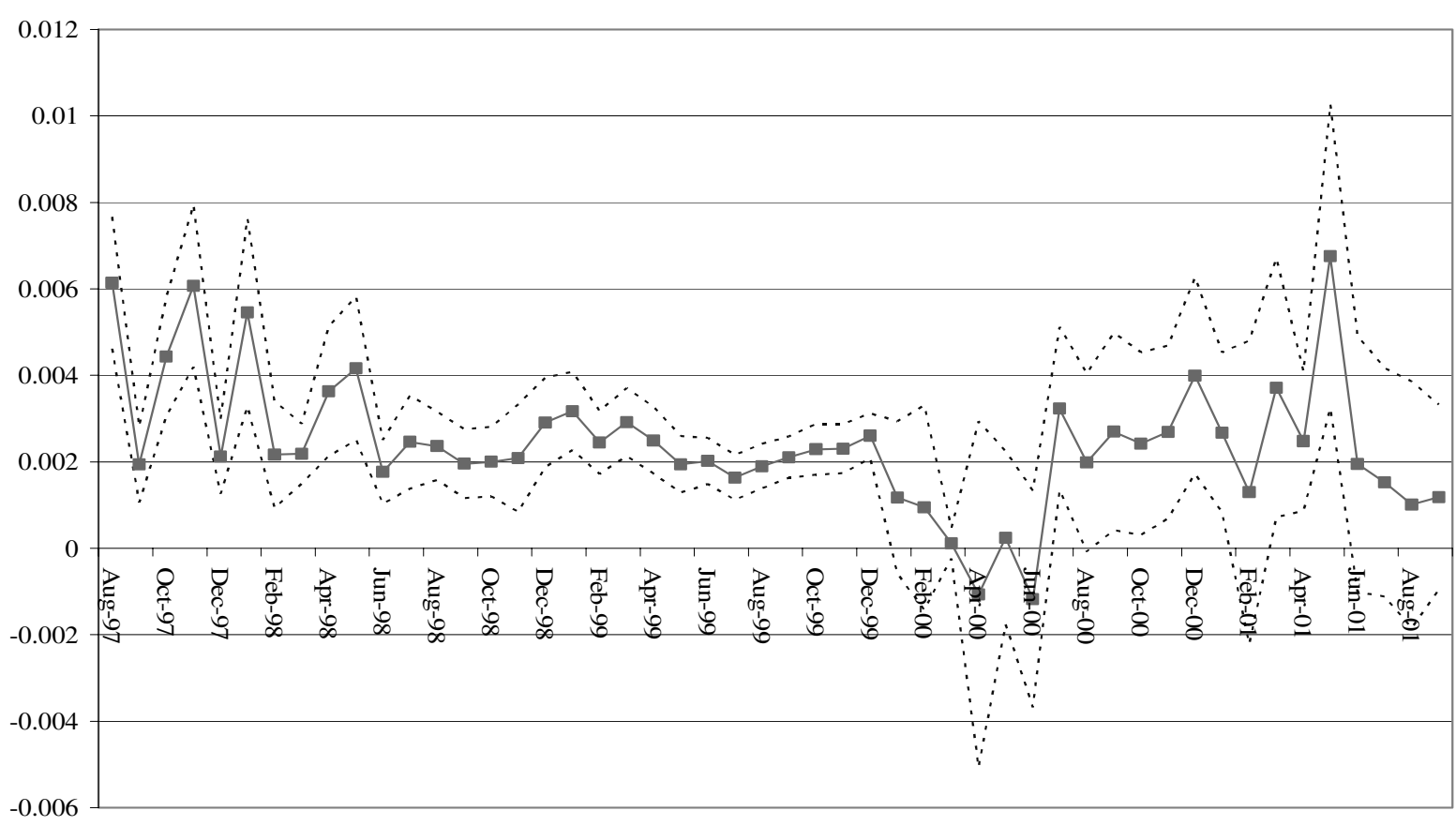

Figure 2: Plot of the Monthly RAM Hedonic Coefficients for Semi-Log Model 
Hard Drive Size Hedonic Coefficients

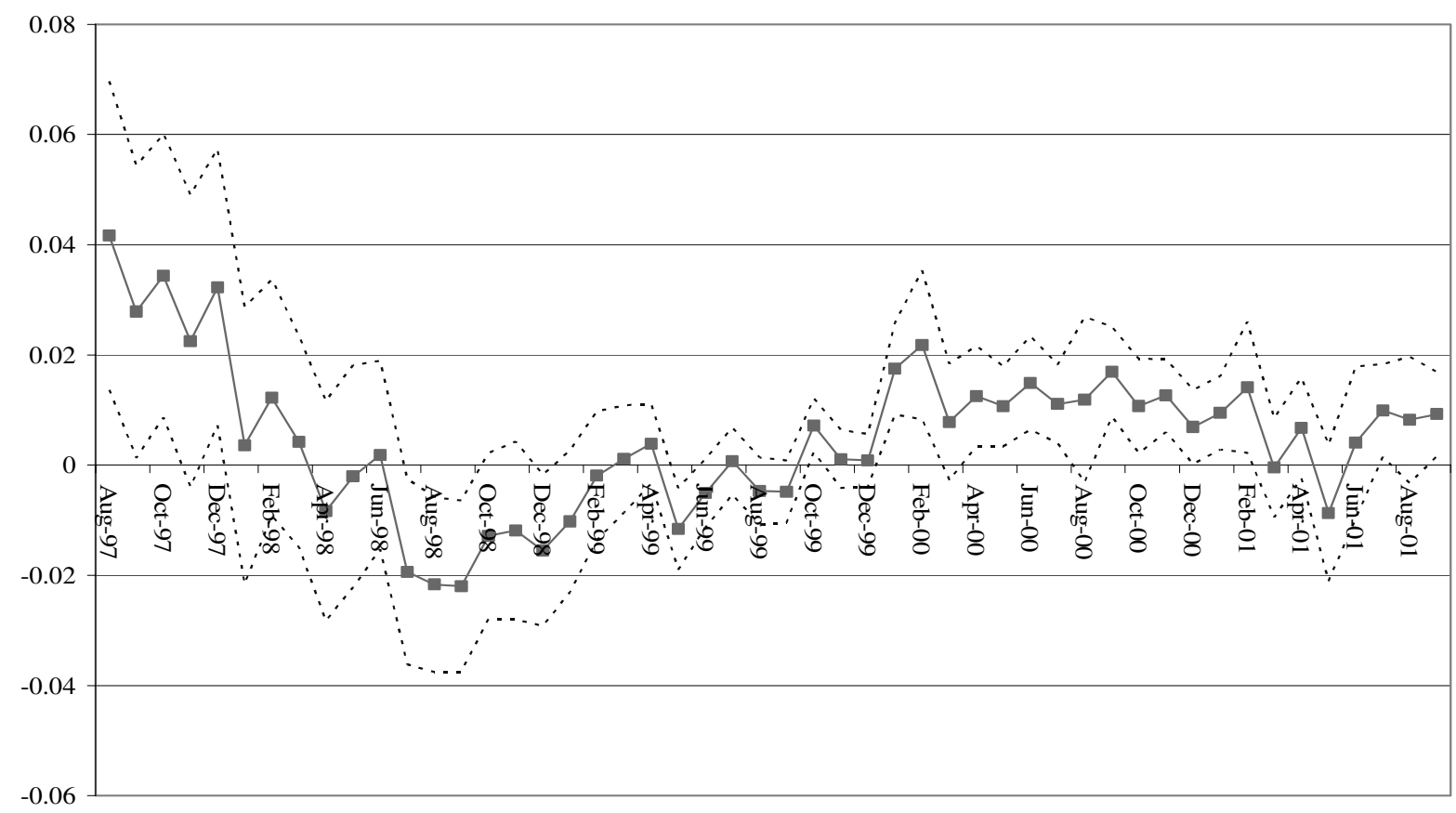

Figure 3: Plot of the Monthly Hard Drive Hedonic Coefficients for Semi-Log Model 


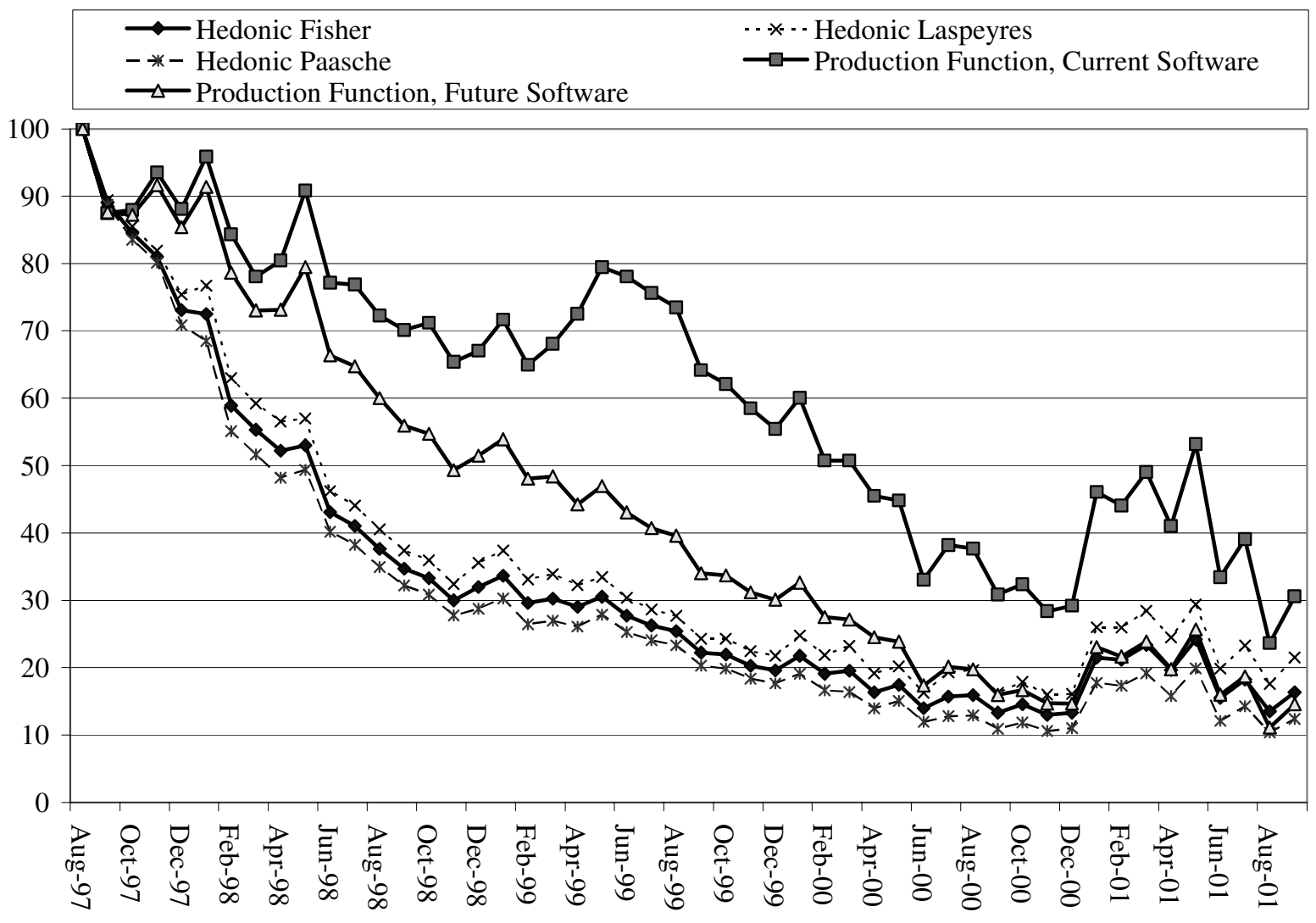

Figure 4: Price Index Calculations 


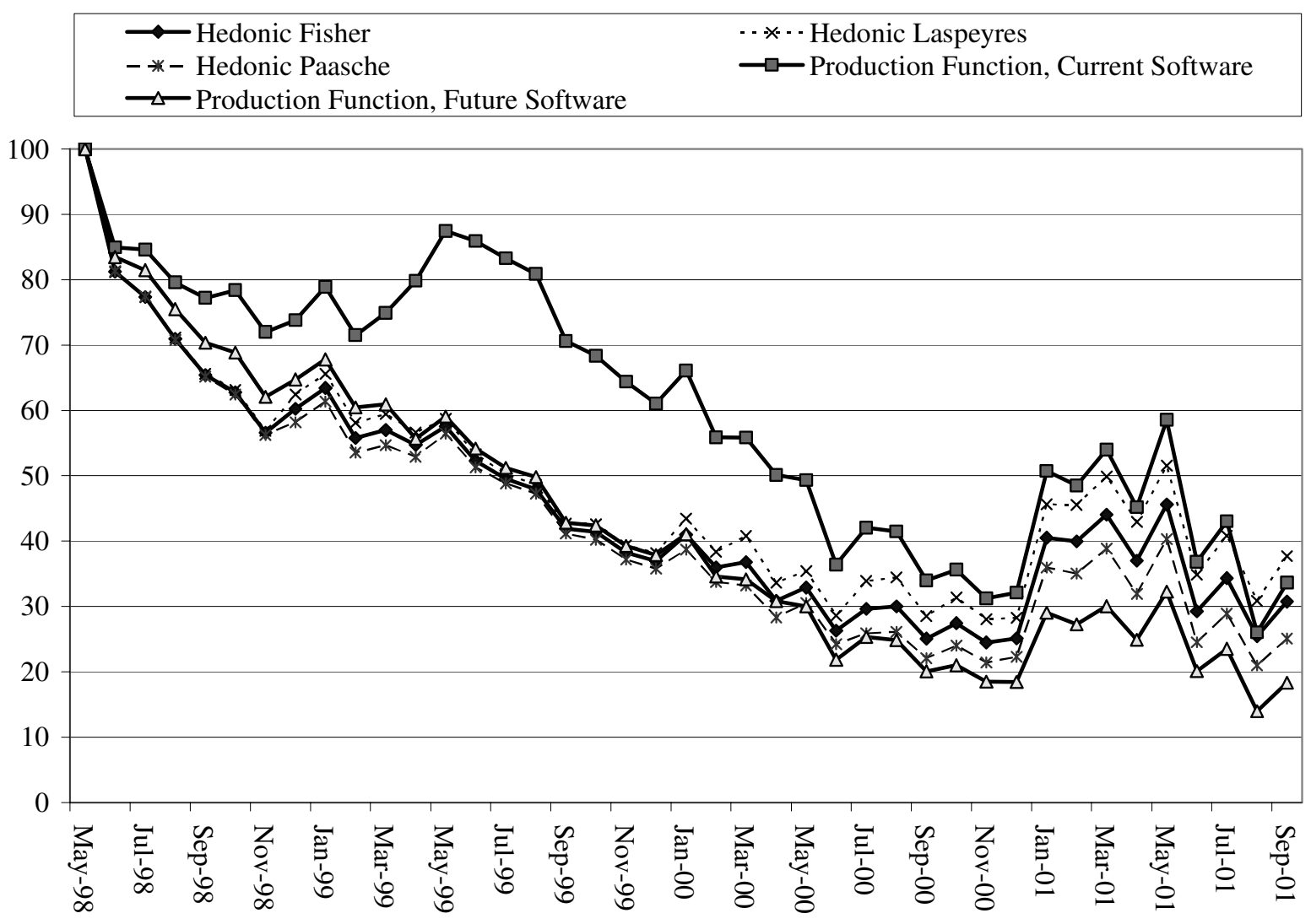

Figure 5: Price Indexes Beginning in May of 1998 


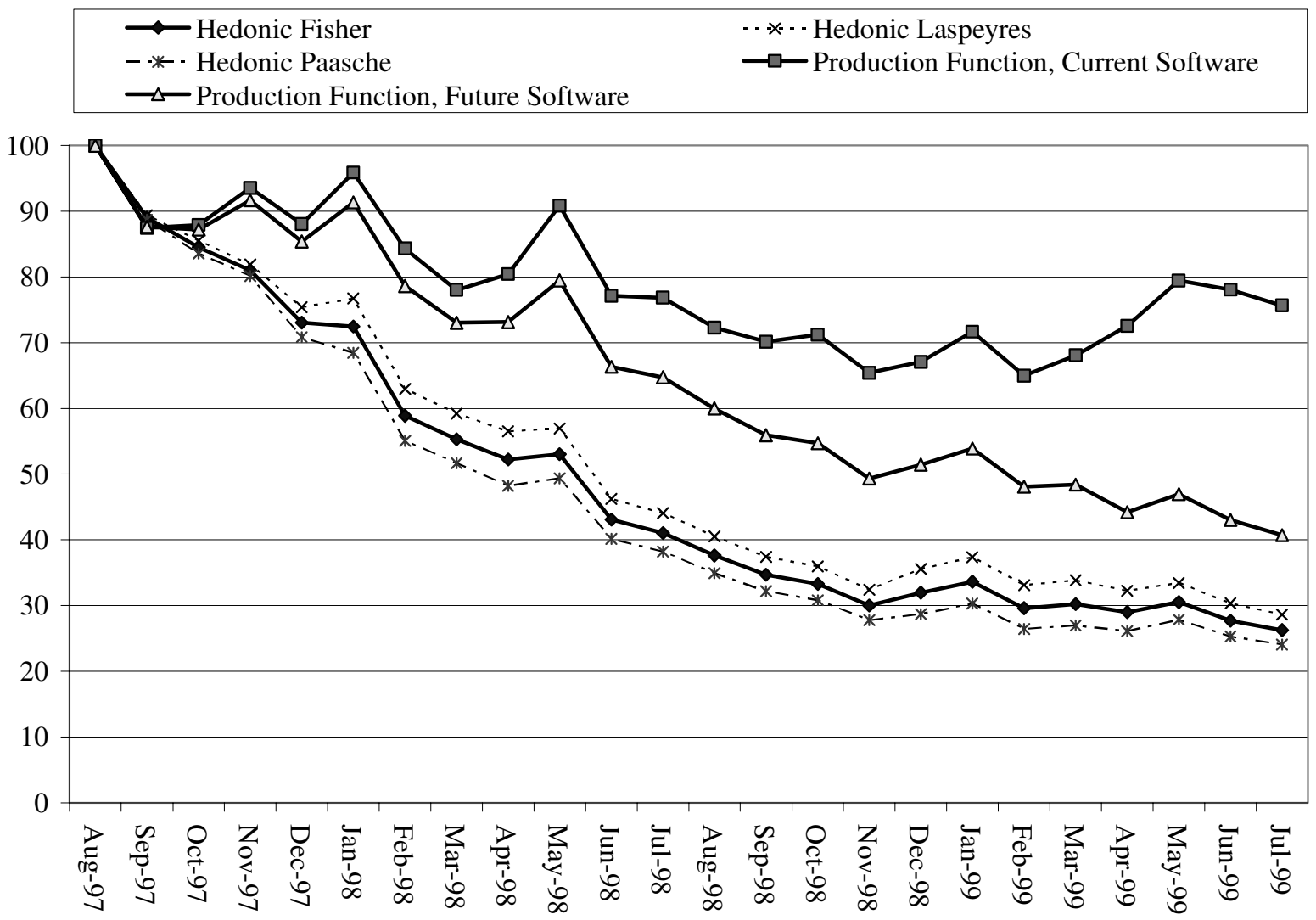

Figure 6: Price Indexes during First Half of the Sample 


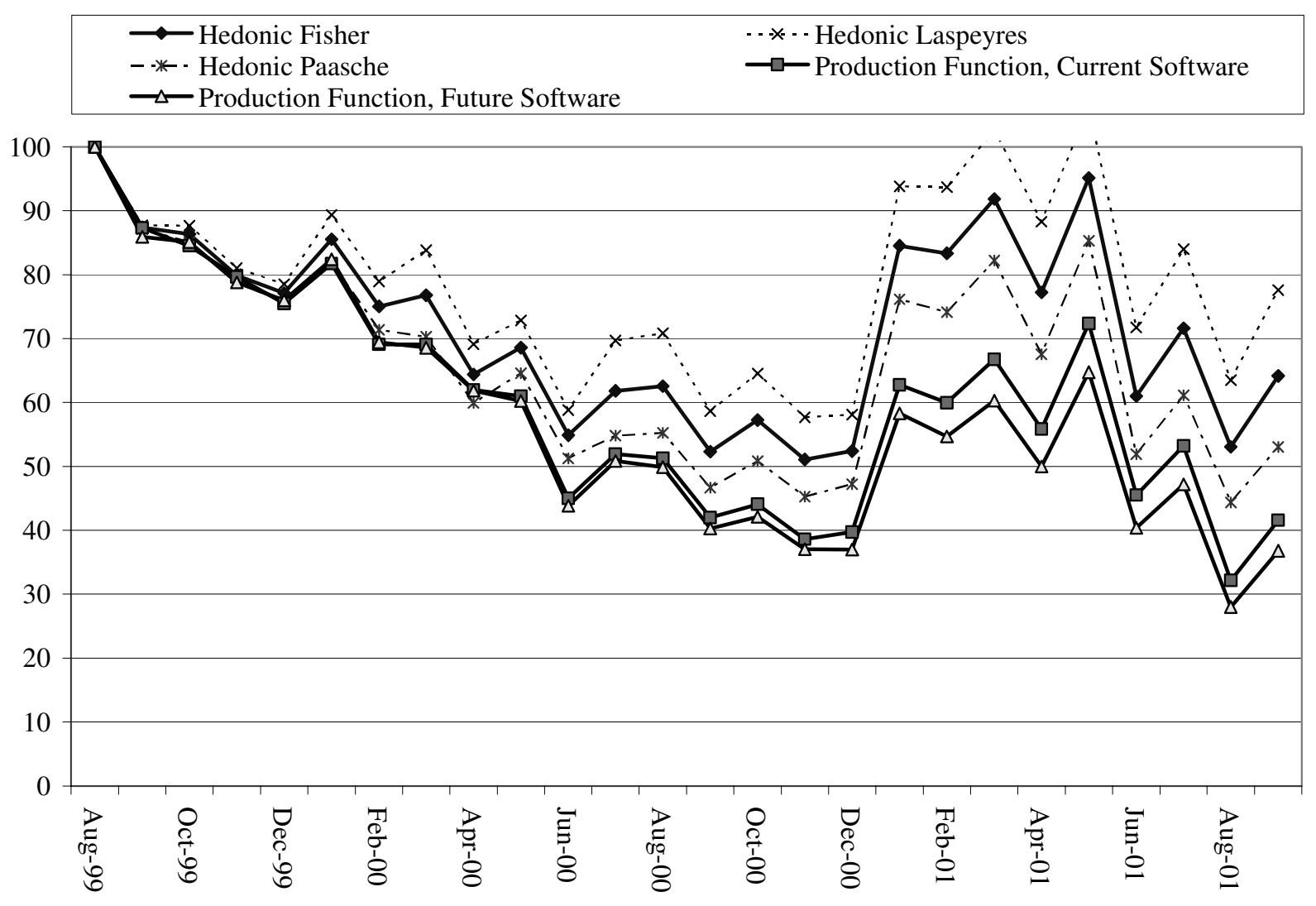

Figure 7: Price Indexes during Second Half of the Sample 
Table 1: Aggregate Summary Statistics

\begin{tabular}{cccccc}
\hline Variable & Mean & Median & Std Dev & Min & Max \\
\hline $\begin{array}{c}\text { Price } \\
\text { Processor }\end{array}$ & 1197.52 & 1088.91 & 5999.20 & 400 & 9430 \\
$\begin{array}{c}\text { speed } \\
\text { Ram }\end{array}$ & 851.971 & 777 & 622.98 & 55 & 7768 \\
$\begin{array}{c}\text { (megabytes) } \\
\text { HD Size }\end{array}$ & 52.505 & 32 & 45.15 & 0 & 1128 \\
$\begin{array}{c}\text { gigabytes) } \\
\text { Have CD? }\end{array}$ & 5.731 & 4.30 & 5.88 & 0 & 200 \\
SCSI? & 0.681 & 1 & - & 0 & 1 \\
Zip Drive? & 0.034 & 0 & - & 0 & 1 \\
NIC? & 0.215 & 0 & - & 0 & 1 \\
Sound Card? & 0.397 & 0 & - & 0 & 1 \\
LCD? & 0.063 & 0 & - & 0 & 1 \\
\hline
\end{tabular}

Sample Size: 32,406 
Table 2: Correlation Matrix of Computer Characteristics

\begin{tabular}{|c|c|c|c|c|c|c|c|c|c|c|}
\hline & Price & $\begin{array}{c}\text { Processor } \\
\text { speed }\end{array}$ & RAM & $\begin{array}{l}\text { HD } \\
\text { Size }\end{array}$ & $\begin{array}{l}\text { Have } \\
\text { CD? }\end{array}$ & SCSI? & $\begin{array}{c}\text { Zip } \\
\text { Drive? }\end{array}$ & NIC? & $\begin{array}{l}\text { Sound } \\
\text { Card? }\end{array}$ & LCD? \\
\hline Price & 1.00 & & & & & & & & & \\
\hline Processor speed & 0.21 & 1.00 & & & & & & & & \\
\hline $\begin{array}{c}\text { Ram } \\
\text { (megabytes) }\end{array}$ & 0.31 & 0.66 & 1.00 & & & & & & & \\
\hline $\begin{array}{c}\text { HD Size } \\
\text { (gigabytes) }\end{array}$ & 0.21 & 0.83 & 0.66 & 1.00 & & & & & & \\
\hline Have CD? & -0.02 & -0.01 & -0.00 & -0.00 & 1.00 & & & & & \\
\hline SCSI? & 0.10 & 0.01 & 0.00 & -0.01 & 0.03 & 1.00 & & & & \\
\hline Zip Drive? & 0.08 & 0.10 & 0.17 & 0.15 & -0.01 & -0.01 & 1.00 & & & \\
\hline NIC? & 0.11 & 0.25 & 0.11 & 0.14 & 0.03 & 0.10 & -0.02 & 1.00 & & \\
\hline Sound Card? & 0.14 & 0.51 & 0.29 & 0.50 & -0.01 & -0.01 & 0.05 & 0.07 & 1.00 & \\
\hline LCD? & 0.07 & 0.12 & 0.09 & 0.14 & 0.03 & 0.00 & -0.01 & 0.02 & 0.10 & 1.00 \\
\hline
\end{tabular}


Table 3: Aggregate Summary Statistics for UC Davis Purchasing Data

\begin{tabular}{cccccc}
\hline Variable & Mean & Median & Std Dev & Min & Max \\
\hline $\begin{array}{c}\text { Price } \\
\text { Processor } \\
\text { speed }\end{array}$ & 2488.72 & 2344.00 & 991.34 & 824 & 18340 \\
$\begin{array}{c}\text { Ram } \\
\text { (megabytes) }\end{array}$ & 1609.78 & 1650 & 858.04 & 272 & 4519 \\
$\begin{array}{c}\text { HD Size } \\
\text { gigabytes) }\end{array}$ & 13.878 & 128 & 131.36 & 0 & 4096 \\
Have CD? & 0.720 & 10 & 12.877 & 0 & 180 \\
SCSI? & 0.068 & 0 & - & 0 & 1 \\
Zip Drive? & 0.389 & 0 & - & 0 & 1 \\
NIC? & 0.704 & 1 & - & 0 & 1 \\
Sound Card? & 0.503 & 1 & - & 0 & 1 \\
LCD? & 0.182 & 0 & - & 0 & 1 \\
\hline
\end{tabular}

Sample Size: 3,718 
Table 4: Summary Statistics for Hedonic Coefficients, Semi-Log Model

\begin{tabular}{cccccc}
\hline Variable & Mean & Std Dev & Min & Max & N \\
\hline $\begin{array}{c}\text { Processor } \\
\text { speed }\end{array}$ & 0.0007 & 0.0003 & 0.0003 & 0.0016 & 50 \\
Ram & 0.0024 & 0.0015 & -0.0012 & 0.0068 & 50 \\
HD Size & 0.0050 & 0.0138 & -0.0219 & 0.0416 & 50 \\
Have CD? & -0.0218 & 0.0746 & -0.1973 & 0.1941 & 49 \\
SCSI? & 0.2239 & 0.1249 & -0.0231 & 0.5398 & 29 \\
Zip Drive? & 0.0283 & 0.1047 & -0.2288 & 0.2631 & 36 \\
NIC? & 0.0567 & 0.0899 & -0.2304 & 0.1905 & 50 \\
Sound Card? & -0.0384 & 0.3867 & -0.9108 & 0.4198 & 29 \\
LCD? & 0.3309 & 0.3623 & -0.7544 & 0.9122 & 31 \\
\hline
\end{tabular}




\section{Table 5: Second Stage Production Function Estimates}

In this table, we report the results from estimating $\beta_{t}=a_{k}+A x_{k t}+\sum \theta_{\mathrm{t}, \tau} \Gamma s_{t+\tau}+u_{k t}$ using data from UC Davis departmental computer purchases from July 1997 to September 2001 using the first stage hedonic pricing coefficients for processor speed, RAM and hard-drive size; the parameter estimates represent the parameters of the production function. The $\theta$ 's are not separately identifiable from the $\Gamma$ 's. Instead, we define the $\theta$ 's by assuming a monthly interest rate of $2 \%$ and that departmental output is constant over the three years. The measure of software quality is the recommended hard-drive space for Microsoft Office and Windows. We assume that each department has an idiosyncratic constant term, $a_{k}$, but departments have the same $A, \theta$ and $\Gamma$.

\begin{tabular}{|c|c|c|c|}
\hline & $\beta_{\text {Speed }}$ & $\beta_{\text {RAM }}$ & $\beta_{\text {HDSize }}$ \\
\hline Speed & $\begin{array}{c}-5.92 \times 10^{-8 * * *} \\
\left(1.01 \times 10^{-8}\right)\end{array}$ & 一 & - \\
\hline RAM & $\begin{array}{c}2.06 \times 10^{-8} \\
\left(2.43 \times 10^{-8}\right)\end{array}$ & $\begin{array}{l}-1.27 \times 10^{-7} \\
\left(1.87 \times 10^{-6}\right)\end{array}$ & - \\
\hline HD Size & $\begin{array}{l}2.47 \times 10^{-6 * * *} \\
\left(2.61 \times 10^{-7}\right)\end{array}$ & $\begin{array}{l}-2.20 \times 10^{-6^{*}} \\
\left(1.26 \times 10^{-6}\right)\end{array}$ & $\begin{array}{c}-6.96 \times 10^{-5 * * *} \\
\left(1.68 \times 10^{-5}\right)\end{array}$ \\
\hline Have CD? & $\begin{array}{c}1.06 \times 10^{-6} \\
\left(7.21 \times 10^{-6}\right)\end{array}$ & $\begin{array}{c}4.20 \times 10^{-5} \\
\left(5.28 \times 10^{-5}\right)\end{array}$ & $\begin{array}{l}-7.33 \times 10^{-3 *} \\
\left(4.28 \times 10^{-3}\right)\end{array}$ \\
\hline SCSI? & $\begin{array}{l}-5.93 \times 10^{-6} \\
\left(1.21 \times 10^{-5}\right)\end{array}$ & $\begin{array}{c}1.29 \times 10^{-4} \\
\left(8.90 \times 10^{-5}\right)\end{array}$ & $\begin{array}{l}-6.78 \times 10^{-4} \\
\left(7.19 \times 10^{-4}\right)\end{array}$ \\
\hline Zip Drive? & $\begin{array}{l}-1.63 \times 10^{-5^{* *}} \\
\left(6.64 \times 10^{-6}\right)\end{array}$ & $\begin{array}{l}8.93 \times 10^{-5^{*}} \\
\left(4.87 \times 10^{-6}\right)\end{array}$ & $\begin{array}{l}-7.66 \times 10^{-5^{*}} \\
\left(3.95 \times 10^{-5}\right)\end{array}$ \\
\hline NIC? & $\begin{array}{c}4.76 \times 10^{-6} \\
\left(6.87 \times 10^{-6}\right)\end{array}$ & $\begin{array}{c}9.04 \times 10^{-6} \\
\left(5.04 \times 10^{-5}\right)\end{array}$ & $\begin{array}{c}-1.78 \times 10^{-3 * * *} \\
\left(4.09 \times 10^{-4}\right)\end{array}$ \\
\hline Sound Card? & $\begin{array}{l}-6.88 \times 10^{-6} \\
\left(6.64 \times 10^{-6}\right)\end{array}$ & $\begin{array}{c}-1.02 \times 10^{-4 * *} \\
\left(4.86 \times 10^{-5}\right)\end{array}$ & $\begin{array}{l}-5.96 \times 10^{-4} \\
\left(3.95 \times 10^{-4}\right)\end{array}$ \\
\hline LCD? & $\begin{array}{l}5.45 \times 10^{-5^{* * *}} \\
\left(9.51 \times 10^{-6}\right)\end{array}$ & $\begin{array}{c}5.76 \times 10^{-5} \\
\left(6.70 \times 10^{-5}\right)\end{array}$ & $\begin{array}{l}1.28 \times 10^{-3 * *} \\
\left(5.51 \times 10^{-4}\right)\end{array}$ \\
\hline$\Gamma_{\text {Office }}$ & $\begin{array}{l}1.62 \times 10^{-3 * * *} \\
\left(1.51 \times 10^{-4}\right)\end{array}$ & $\begin{array}{c}-5.10 \times 10^{-4 * * *} \\
\left(1.27 \times 10^{-4}\right)\end{array}$ & $\begin{array}{c}8.25 \times 10^{-4} \\
\left(3.04 \times 10^{-4}\right)\end{array}$ \\
\hline$\Gamma_{\text {Windows }}$ & $\begin{array}{l}-8.35 \times 10^{-5^{* *}} \\
\left(4.11 \times 10^{-5}\right)\end{array}$ & $\begin{array}{l}4.96 \times 10^{-4 * * *} \\
\left(4.27 \times 10^{-5}\right)\end{array}$ & $\begin{array}{l}-8.29 \times 10^{-6} \\
\left(5.04 \times 10^{-6}\right)\end{array}$ \\
\hline
\end{tabular}

$\mathrm{N}=3931$. White's heteroskedastic consistent standard errors in parentheses. * denotes significant at the .10 level, ${ }^{* *}$ significant at the .05 level, and ${ }^{* * *}$ significant at the .01 level.

Notes: An F-test marginally rejects symmetry between the processor speed and hard drive equations (pvalue equal to 0.126 ). Equality between the processor speed and RAM equations and the hard drive and RAM equations cannot be rejected (p-values equal to 0.617 and 0.402 , respectively). The results with respect to software quality remain qualitatively unchanged if symmetry is not imposed. Including a time trend also left the results qualitatively unchanged. 
Table 6: Average Annual Growth Rates of Price Indexes

\begin{tabular}{lccc}
\hline & $\begin{array}{c}\text { Hedonic } \\
\text { Fisher index }\end{array}$ & $\begin{array}{c}\text { Production Function, } \\
\text { Current Software }\end{array}$ & $\begin{array}{c}\text { Production Function, } \\
\text { Future Software }\end{array}$ \\
\hline Entire Sample* & -36.4 & -25.5 & -38.2 \\
First Half & -51.3 & -13.6 & -38.0 \\
Second Half & -19.9 & -34.7 & -38.3 \\
1997 & -62.4 & -32.1 & -38.3 \\
1998 & -57.6 & -24.1 & -40.4 \\
1999 & -39.3 & -17.4 & -42.2 \\
2000 & -32.5 & -48.3 & -52.4 \\
2001 & 30.6 & -6.3 & 0.7 \\
\hline
\end{tabular}

